OPEN ACCESS

Edited by:

Robert Sargis,

University of Illinois at Chicago,

United States

Reviewed by:

Víctor M. Arce,

Universidade de Santiago de

Compostela, Spain

Chun-Xia Yi,

Academic Medical Center (AMC)

Netherlands

*Correspondence:

Pushplata Prasad Singh

pushplata.singh@teri.res.in

Specialty section:

This article was submitted to

Systems and Translational

Endocrinology,

a section of the journal

Frontiers in Endocrinology

Received: 28 June 2018 Accepted: 08 November 2018

Published: 26 November 2018

Citation:

Priyam A, Singh PP and Gehlout S (2018) Role of Endocrine-Disrupting

Engineered Nanomaterials in the Pathogenesis of Type 2 Diabetes Mellitus. Front. Endocrinol. 9:704. doi: 10.3389/fendo.2018.00704

\section{Role of Endocrine-Disrupting Engineered Nanomaterials in the Pathogenesis of Type 2 Diabetes Mellitus}

\author{
Ayushi Priyam, Pushplata Prasad Singh* and Shweta Gehlout \\ TERI Deakin Nanobiotechnology Centre, The Energy and Resources Institute, New Delhi, India
}

Nanotechnology has enabled the development of innovative technologies and products for several industrial sectors. Their unique physicochemical and size-dependent properties make the engineered nanomaterials (ENMs) superior for devising solutions for various research and development sectors, which are otherwise unachievable by their bulk forms. However, the remarkable advantages mediated by ENMs and their applications have also raised concerns regarding their possible toxicological impacts on human health. The actual issue stems from the absence of systematic data on ENM exposure-mediated health hazards. In this direction, a comprehensive exploration on the health-related consequences, especially with respect to endocrine disruption-related metabolic disorders, is largely lacking. The reasons for the rapid increase in diabetes and obesity in the modern world remain largely unclear, and epidemiological studies indicate that the increased presence of endocrine disrupting chemicals (EDCs) in the environment may influence the incidence of metabolic diseases. Functional similarities, such as mimicking natural hormonal actions, have been observed between the endocrine-disrupting chemicals (EDCs) and ENMs, which supports the view that different types of NMs may be capable of altering the physiological activity of the endocrine system. Disruption of the endocrine system leads to hormonal imbalance, which may influence the development and pathogenesis of metabolic disorders, particularly type 2 diabetes mellitus (T2DM). Evidence from many in vitro, in vivo and epidemiological studies, suggests that ENMs generally exert deleterious effects on the molecular/hormonal pathways and the organ systems involved in the pathogenesis of T2DM. However, the available data from several such studies are not congruent, especially because of discrepancies in study design, and therefore need to be carefully examined before drawing meaningful inferences. In this review, we discuss the outcomes of ENM exposure in correlation with the development of T2DM. In particular, the review focuses on the following sub-topics: (1) an overview of the sources of human exposure to NMs, (2) 
systems involved in the uptake of ENMs into human body, (3) endocrine disrupting engineered nanomaterials (EDENMs) and mechanisms underlying the pathogenesis of T2DM, (4) evidence of the role of EDENMs in the pathogenesis of T2DM from in vitro, in vivo and epidemiological studies, and (5) conclusions and perspectives.

Keywords: engineered nanomaterial (ENM), type 2 diabetes mellitus (T2DM), endocrine disruptor, insulin resistance, reduced insulin sensitivity, oxidative stress, in vitro and in vivo studies, epidemiological evidences

\section{BACKGROUND}

Materials acquire unique characteristics when the size of the particle is reduced to nanoscale. Nanomaterials (NMs) are a universal set of nanoscale materials having at least one of the dimensions in the nano-range. With having at least one dimension in nanoscale as a common feature, nanoparticles, nanowires, nanosheets, nanotubes, and nanoplates can be stated as the key subsets of NMs (1). The various properties of a nanomaterial (NM), including its melting point, electrical conductivity, magnetic permeability, chemical reactivity and fluorescence, are determined by the particle size (2). Sizereduction of a material to nanoscale enhances its functional aspects and associated technological benefits. Therefore, the use of engineered nanomaterials (ENMs) in the development of advanced technologies for medicine, engineering and natural sciences has significantly increased since the start of the twentyfirst century (3). ENMs are being incorporated into our everyday routine as a part of clothing, food, cosmetics, medicines,

\footnotetext{
Abbreviations: AgNPs, Silver Nanoparticles; Ahr, Aryl Hydrocarbon Receptor; AKT, Alpha Serine/Threonine Kinase; ALS, Alloxan Sensitive; AMPK, AMP Activated Protein Kinase; AR, Androgenic Receptor; AuNPs, Gold Nanoparticles; B7/CD28, Immunoglobulin Superfamily Members; BrdU, Bromodeoxyuridine; CARDIA, Coronary Artery Risk Development In Young Adults; CdTe Qds, Cadmium Telluride Quantum Dots; $\mathrm{CeO}_{2}-\mathrm{NPs}$, Cerium Oxide Nanoparticles; CHOP, CCAAT-Enhancer-Binding Protein Homologous Protein; Cpg-Odns, Cpg Oligodeoxynucleotides; CrNano, Chromium Nanoparticles; CRP, C-Reactive Protein; EDCs, Endocrine-Disrupting Chemicals; EDENM, Endocrine-Disrupting ENM; ENM, Engineered Nanomaterial; ER, Estrogen Receptors; G6PDH, Glucose-6-Phosphate Dehydrogenase; GI, Gastrointestinal tract; GK, GotoKakizaki; GLUT, Glucose Transporter; GNPs, Gold Nanoparticles; GPR30, G-Protein-Coupled Receptor For Estrogen; GPX, Glutathione Peroxidase; GR, Glutathione Reductase; GSH, Glutathione; GSK, Glycogen Synthase Kinase; $\mathrm{H}_{2} \mathrm{O}_{2}$, Hydrogen Peroxide; HIP, Human Amyloid Polypeptide; IFG, Impaired Fasting Glucose; IFN, Interferon; IL, Interleukin; INS-GNPs, Insulin-Coated Gold Nanoparticles; IONPs, Iron Oxide $\left(\mathrm{Fe}_{2} \mathrm{O}_{3}\right)$ Nanoparticles; IPCS, International Programme On Chemical Safety; IR, Insulin Receptor; IRE-1, Inositol-Requiring Enzyme 1; IRS, Insulin Receptor Substrate; JNK, C-Jun N-Terminal Kinases; LDL, Low Density Lipoproteins; MCP1, Monocyte Chemoattractant Protein 1; MDA, Malondialdehyde; MIMIC, Modular Immune in vitro Construct, An Artificial System Imitating The Human Immune System; MSNs, Mesoporous Silica Nanoparticles; Mtor, Mammalian Target of Rapamycin; NMs, Nanomaterials; NPs, Nanoparticles; PEG-B-PLGA, Biodegradable Polyethylene Glycol And Poly (Lactic-Co-Glycolic Acid) Copolymer; PI3K, Phosphatidylinositol 3-Kinase; PPAR, Peroxisome Proliferator Activated Receptor; PR, Progesterone Receptor; PTP, Phosphotyrosine Phosphotase; rHEGF, Recombinant Human Epidermal Growth Factor; ROS, Reactive Oxygen Species; SD, Sprague-Dawley; SeNPs, Selenium Nanoparticles; SNP, Single Nucleotide Polymorphisms; SOD, Superoxide Dismutase; T2DM, Type 2 Diabetes Mellitus; $\mathrm{TiO}_{2}-\mathrm{NPs}$, Titanium Oxide Nanoparticles; TNF- $\alpha$, Tumor Necrosis Factor -A; UFPs, Ultrafine Particles; WHO, World Health Organization; ZON, Zinc Oxide Nanoparticles; $\beta$-Cells, Beta Cells.
}

electronic goods, etc. However, in parallel to the technological advancements, the biosafety issues related to ENMs have also become a matter of apprehension. Whereas, for applications in medicine, ENMs are optimized to enhance their cellular uptake and/or targeting to the desired tissue, an inadvertent exposure to workers may raise health concerns $(4,5)$. Multiple studies have suggested that unlike their bulk counterparts, the ENMs are highly toxic and may lead to serious human and ecological health risks (6-8). The toxic outcomes of ENM exposure are largely accredited to their small size and increased chemical reactivity, which enhances their permeability to the target tissues which are otherwise not penetrated by larger but chemically identical materials (9). Noticeably, evidence from several research studies indicates functional similarities between the endocrinedisrupting chemicals (EDCs) and ENMs, which supports the view that different types of NMs may be capable of altering the physiological activity of the endocrine system (10-14).

The WHO (World Health Organization) International Programme on Chemical Safety (IPCS) conducts research to understand the basis for the management of chemicals and related risks. According to the IPCS, "a potential endocrine disruptor is an exogenous substance or a mixture, possessing properties that can lead to endocrine disruption in an intact organism, or its progeny, or (sub) populations" (15). Further to add, the EDCs are elements present in our environment, food, and several consumer products that can interfere with synthesis, secretion, transport, metabolism, binding actions and elimination, and mimic the natural hormones. Consequently, this may lead to a deviation from the normal physiological function of the endocrine system to endocrine disruption. The EDCs and endocrine disrupting ENMs (EDENMs) are prevalent in various consumer goods such as agricultural chemicals, notably fertilizers and pesticides $(16,17)$, therapeutics (18), cosmetics $(19,20)$, and paints (19). There is accumulating evidence suggesting an increased presence of EDCs and ENMs in the environment, which putatively affects the functioning of the endocrine system, metabolic system and reproductive system (Figure 1). Hence, though the ENMs promise remarkable benefits, their successful application requires investigation of their impact on human health.

Both EDCs and NMs are regularly investigated for adverse impacts on health. Studies conducted to evaluate the effects of EDCs on health have generally reported deleterious outcomes like altered reproductive function in males and females (2125 ), increased incidence of breast cancer (26-30), abnormal growth patterns (31-33), neurodevelopmental delays in children (34-36), and changes in immune functions (37-39). Similarly, exposure to NMs is found to be associated with 


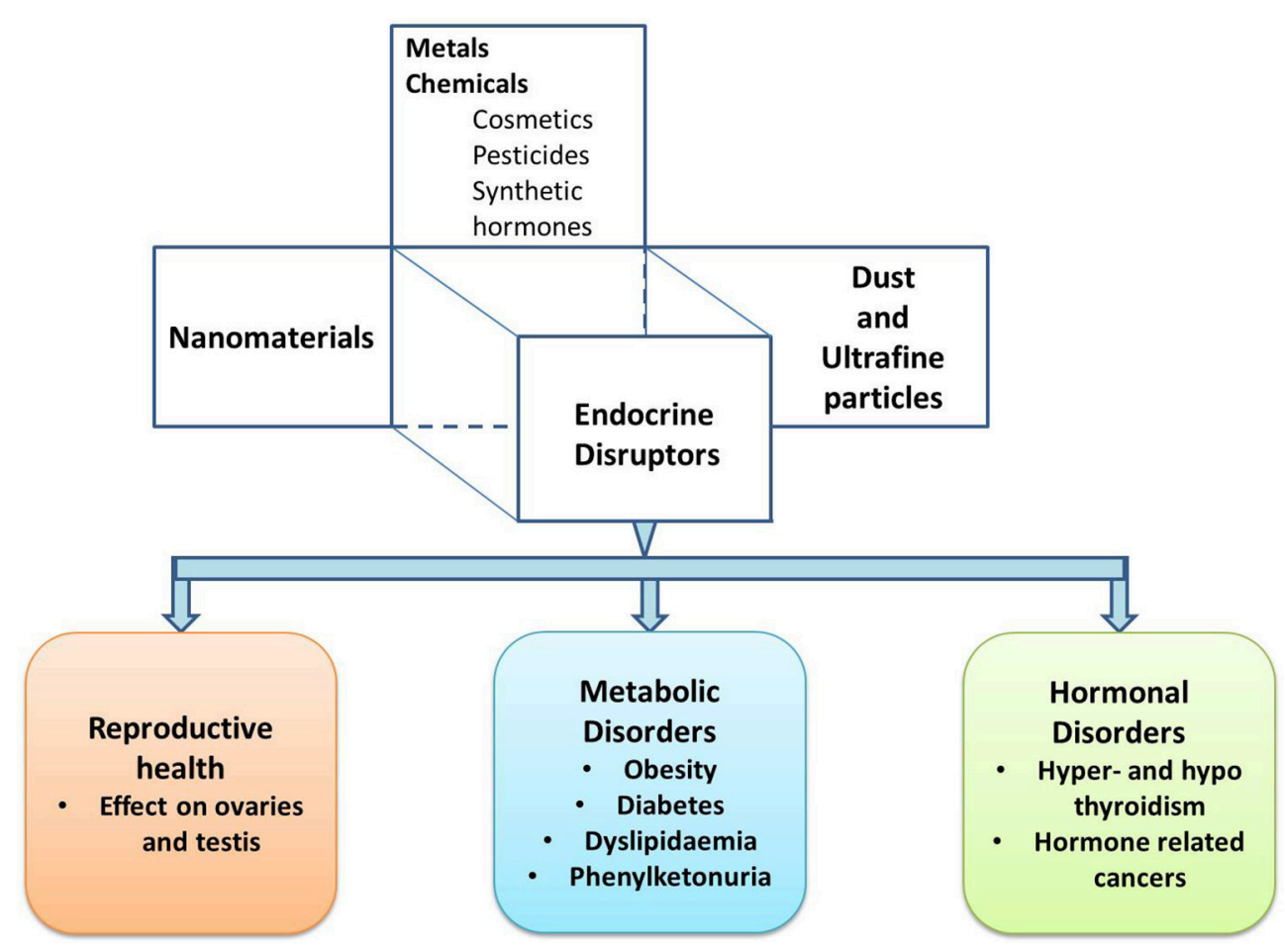

FIGURE 1 | A schematic describing different types of endocrine disruptors and the associated endocrine disorders.

several adverse outcomes such as impaired immune response, inflammation, fibrosis, emphysema, and tumor formation (40-45).

Additionally, EDCs have been reviewed to act as causative agents of metabolic disorders like type 2 diabetes mellitus (T2DM) $(46,47)$. The prevalence of T2DM has seen a tremendous global upsurge during the last few decades. A report from the International Diabetes Federation (IDF) estimated $\sim 425$ million adults (aged between 20 and 79 years) all over the world were living with diabetes in 2017 and predicted that by 2045 this will rise to 629 million. A large number of investigations to define the genetic and environmental bases of T2DM has been done to date but the definite reasons for a rapid increase in diabetes and obesity in the modern world largely remain unclear. Research in the arena increasingly indicates a major role played by environmental chemicals in diabetes and obesity, advocating that the environmental led metabolism disruption could form the "paradox of progress" (48). At present, only a few studies have examined the role of ENMs in the pathogenesis of T2DM. Chevalier and Fénichel reviewed both in vivo and in vitro experimental data along with epidemiological evidence to support an association of EDC exposure to the induction of insulin resistance and/or disruption of pancreatic $\beta$-cell function that leads to glucose homoeostasis related metabolic disorders (49). The evidence of ENM mediated alterations in glucose metabolism, insulin resistance and sensitivity, and homeostasis pathways are mostly indirect. The influence of EDENMs on the candidate genes of T2DM and their further impact on various molecular pathways are scarcely defined at present. Herein, we reviewed the recent literature that presented the effects of ENMs on molecular pathways involved in the development of T2DM. We also identified the knowledge gaps and challenges in the research area, which may provide directions for future research.

\section{AN OVERVIEW OF THE SOURCES OF HUMAN EXPOSURE TO NANOMATERIALS (NMs)}

The probability of exposure to NMs in humans (50, 51) increases not only during production and application of ENMs, but also due to their emergence through several natural processes.

\section{Natural Sources of NMs}

We generally correlate exposure to NMs with human activities like the automobile industry, building construction and charcoal burning. However, 90\% of the nano-particulate matter present in the environment is produced through natural phenomena such as dust storms, forest fires and volcanic eruptions, which significantly pollute natural resources, and affect human health. Dust storms are the main source of environmental NMs which can lead to respiratory issues, especially in subjects suffering from asthma and emphysema. Furthermore, dust rich in metal particles can lead to the generation of reactive oxygen species (ROS) (52), which may lead to an inflammatory response and 
influence pathogenesis of life style disorders such as T2DM and heart disorders.

\section{Anthropogenic Sources of NMs}

ENMs comprise the main category of anthropogenic release of NMs in the environment. These are produced and released into the environment by either intentional or unintentional human activities. The unintentional release of NMs occurs from the burning of natural fuels, wood, and wax (53-56). The intentional release occurs through the discharge of ENMs to rivers, landfills, soils and wastewater-treatment plants as well as from engineered products with embedded NMs. Intentional activities include the commercial synthesis of NMs, combustion of fossil fuel, manufacturing of NM embedded products, etc. Such products have found applications in biomedical, pharmaceutical, and agricultural domains. ENMs are rapidly being used in pharmaceuticals as carriers $(57,58)$ and as nano-formulations of drugs (59-61) and for electro-analysis of pharmaceuticals $(62,63)$. ENMs also find diverse applications in agriculture (64) to increase the productivity by providing nano-scaled solutions primarily as pesticides (65), fertilizers (65), and biosensors (66). A fraction of these ENMs may also make their way into soil and water ecosystems, and therefore into drinking water and food products (67-69). Such observations have raised concerns regarding the presence of ENMs in consumer products and plausible association with human health and environmental degradation.

\section{SYSTEMS INVOLVED IN UPTAKE OF ENMS INTO THE HUMAN BODY}

Both natural and anthropogenic NMs enter the human body primarily through the respiratory system, skin and gastrointestinal (GI) tract, with further translocation to different tissues and organs as depicted in Figure $2(71,72)$. Considering the plethora of anthropogenic NMs, many ENMs may not be effectively removed and therefore can accumulate in different organ-systems over a period. Various cell types by which the ENMs are internalized include macrophages (73-75) endothelial cells (76), pulmonary epithelial cells (77-79), the gastrointestinal epithelium (80), blood cells (81), and neurons (82). Depending on their cellular concentration, the nanoscale particulate matter can mediate mutagenesis, damage to cell organelles, and eventually cell death.

\section{Respiratory System}

The ENMs most prominently reach the body by inhalation and deposit throughout the entire respiratory tract $(41,70,83)$. The soluble kinds of ENMs such as branched polyethylenimine and arginylglycylaspartic acid (RGD) based hydrophilic ENMs can be dissolved in the aqueous fluid lining the epithelium and can escape into the circulatory and lymphatic systems. However, the insoluble ENMs like nano-formulations of $\mathrm{Au}$, $\mathrm{Ag}, \mathrm{Ti}, \mathrm{Si}$, carbon etc., may accumulate in the lungs upon continued exposure, resulting in injury to the lung tissue (84). Recent research has demonstrated that inhalation of ENMs can deregulate the immune system and diminish the ability to fight infections (85). Also, as depicted in Figure 2, ENM exposure through the respiratory tract has been found to be associated with respiratory disorders, namely asthma (86), bronchitis $(87,88)$, and emphysema $(89,90)$; neuro-degenerative disorders, namely Alzheimer's (91), and Parkinson's (92, 93); and heart diseases (84).

\section{Skin}

The extent of the uptake of ENMs by human skin is still debatable. The outer layer (stratum corneum) of the skin consists of a layer of dead cells and is generally impervious to materials having a pore diameter greater than micron size (94). However, many research studies show that NPs can penetrate the stratum corneum (95-97), especially when the skin is flexed. Dermal exposure of ENM has been reported to be associated with dermatitis (eczema) (98-100).

\section{Gastrointestinal System}

ENMs present in food and cosmetics may enter the human body through ingestion by the gastrointestinal (GI) system. Nanoenabled applications, especially those for the food industry, dental care products and cosmetics, may lead to ENM exposure related toxicity (101-103) in humans. Major ENMs that are reported to cause cytotoxicity when ingested include nano-forms of gold, silver, and metal oxides of zinc, silica, and titanium (104-108). As also depicted in Figure 2, exposures to these NMs through the GI can lead to Crohn's disease, Colon disease and Gastroenteritis (109).

\section{ENDOCRINE DISRUPTING ENGINEERED NANOMATERIALS (EDENMS) AND MECHANISMS UNDERLYING THE PATHOGENESIS OF TYPE 2 DIABETES MELLITUS (T2DM)}

A global spike in the production of ENM has been observed in the twenty-first century, which has enhanced the exposure rate among workers and users. At present no occupational exposure level (OEL) for ENM has been defined and the assessment of exposure to ENM is challenging. Several research groups through various experimental models have demonstrated that ENM can elicit toxic responses that may be inferred from abnormalities in various organ-systems (110-113). The extent of toxicity conferred by ENM has been reported to depend upon their physicochemical properties including size, shape, chemical nature, and surface functionalization. The cytotoxic nature of ENM could eventually lead to cell death in a dose-and timedependent manner (114). On the other hand, some other research studies that conducted short-term experiments on cultured cells and model organisms in order to evaluate the biocompatibility of ENM (115) suggested a low level of cytotoxicity of ENM. These studies advocated a huge potential for in vivo applications of ENM in the form of therapeutic and diagnostic reagents, although the effects related to a long-term exposure remain an unexplored domain at present. The studies on the longterm effects of ENM in vivo hold significant importance in 


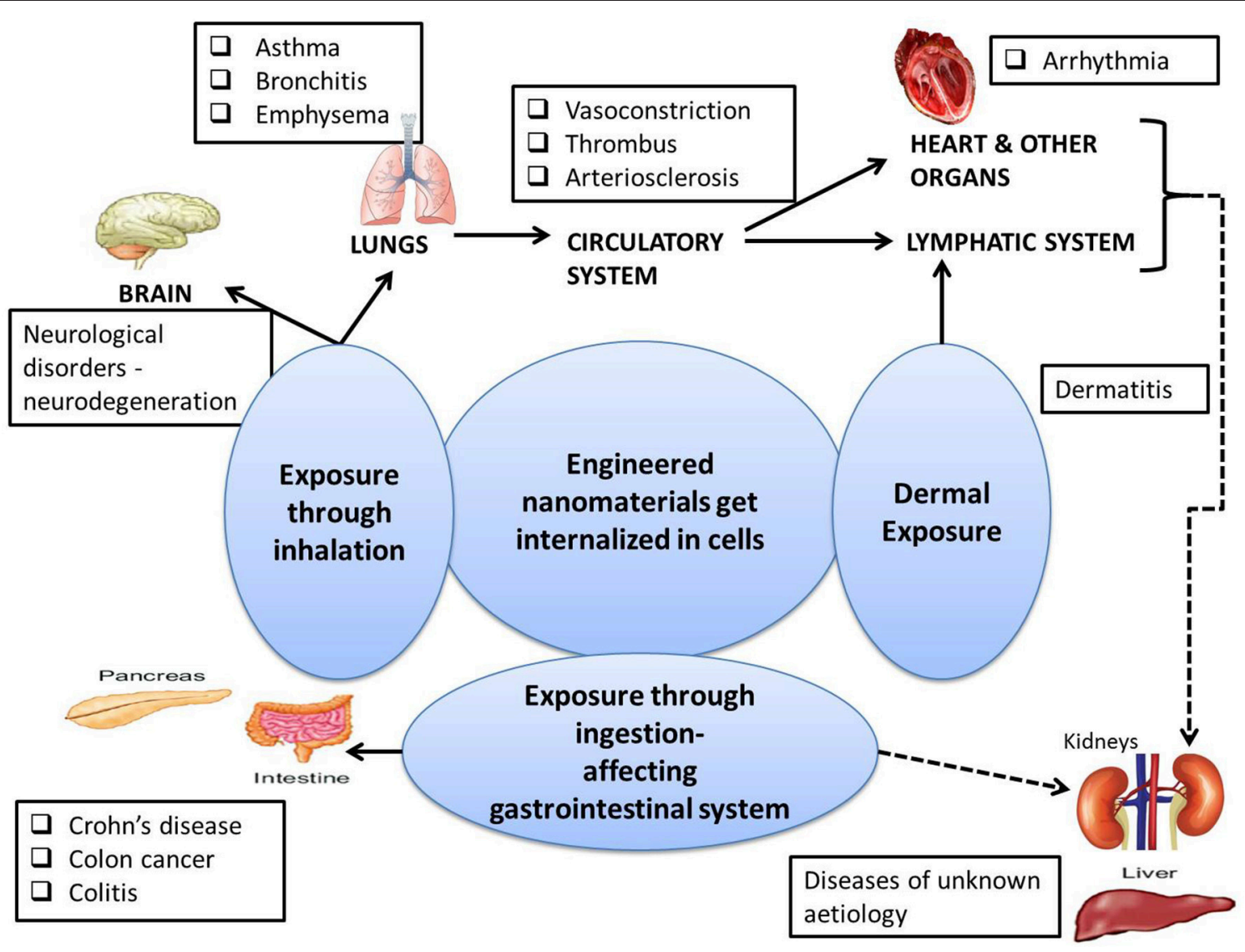

FIGURE 2 | A concise overview of affected organs resulting in various pathological states due to the exposure to ENMs as described in the literature (42, 70). The directly and indirectly affected systems are shown by solid and dashed lines respectively.

designing and development of next-generation materials, but the mechanisms underlying ENM mediated toxicity in humans are less understood (116), Particularly, whether ENM exposure leads to endocrine-disruption and influences development of T2DM among the exposed subjects remains a topic of investigation.

Contemporary in vitro, in vivo and epidemiological studies link human EDC exposure with obesity, T2DM and metabolic syndrome (47). Endocrine disruptors have a tendency to interact with the cellular receptors either by mimicking the natural hormones (Figure 3A) or by blocking the action of hormones (Figure 3B) (117).

Some studies have revealed the harmful effects of ENMs on endocrine functions, which suggests that ENMs may behave as potential endocrine disruptors, EDENMs (118-121). It is well acknowledged that endocrine disruption can often lead to the onset of metabolic disorders such as T2DM (122). Therefore, it is suggested that the ENM, which reportedly affects endocrine function, may induce T2DM. The EDENMs can behave in a similar fashion as the EDCs $(13,123,124)$. The additional aspects of EDENMs over the traditional EDCs are small size, increased surface area and better uptake capability. Such properties of EDENMs enhance their chances of uptake and bioavailability, which further amplifies the deteriorating effect of the material on metabolic homeostasis (125-129) when compared to the other EDCs.

Working on similar ground as that of endocrine disruptors, ENMs may alter the normal metabolic state by affecting glucose homeostasis, leading to T2DM via the two chief mechanisms (Figure 4)-(i) decreasing insulin sensitivity and (ii) impairment of beta $(\beta)$-cells, resulting in a deleterious effect on insulin production (130-132).

\section{Reduced Insulin Sensitivity}

Several factors lead to a reduction in cellular insulin sensitivity. Using the available in vitro, in vivo and epidemiological data, here we reviewed and illustrated the prominent mechanisms leading to decreased insulin sensitivity. The major focus in this review has been laid out-impairment of cellular insulin action, interaction with hormonal receptors, inflammation, and variations in homeostatic pathways. Each of these factors is explained in the following sections with evidence to show the deleterious effect of ENM on the pathogenesis of T2DM.

\section{Impairment of Cellular Insulin Action}

Cellular metabolic reactions are often mediated by insulin via its action on the plasma membrane, intracellular enzymes and the 

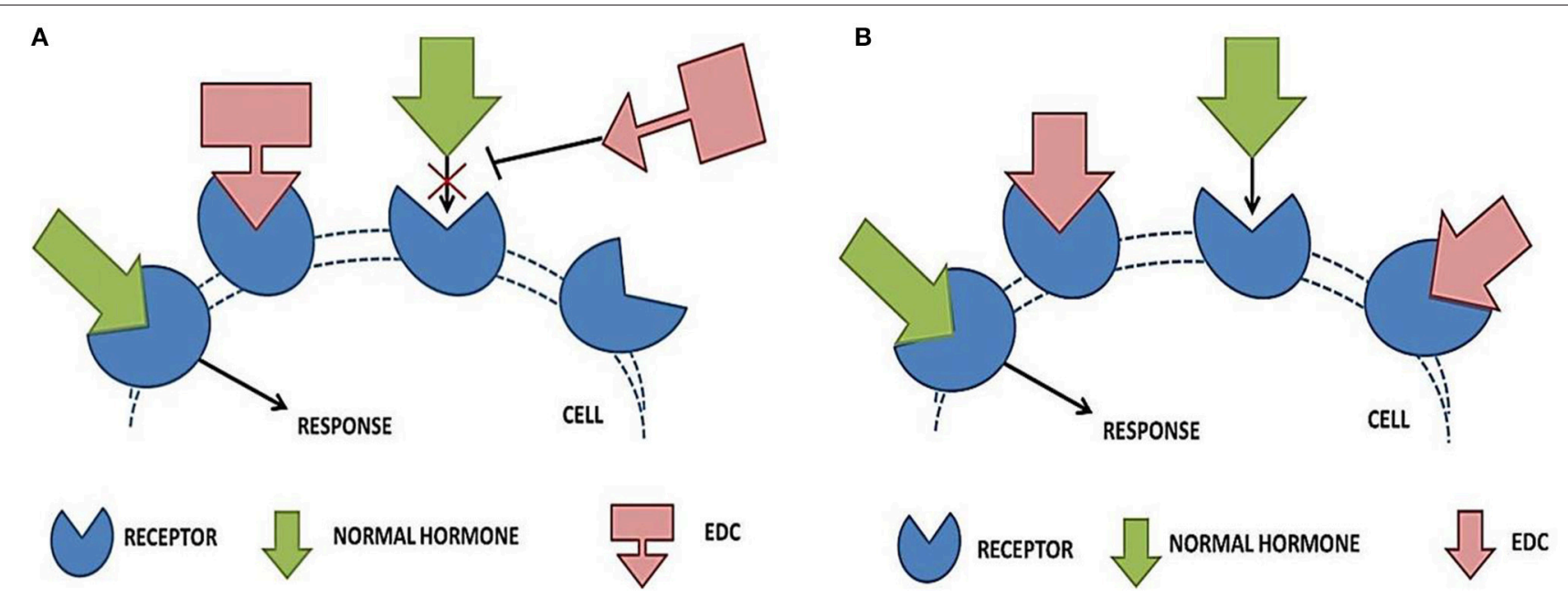

FIGURE 3 | Effect of endocrine disrupting chemicals on receptor-hormone interaction. (A) Shows the blocking action of EDCs, where it binds to the receptor within the cell and blocks the endogenous hormone from binding. The normal signaling is blocked and the associated organ system (liver and pancreas) fails to respond properly. In (B), the mimicking action of EDCs is depicted. EDCs completely or partially mimic the naturally occurring hormones, thereby interfering with the obvious physiological responses.

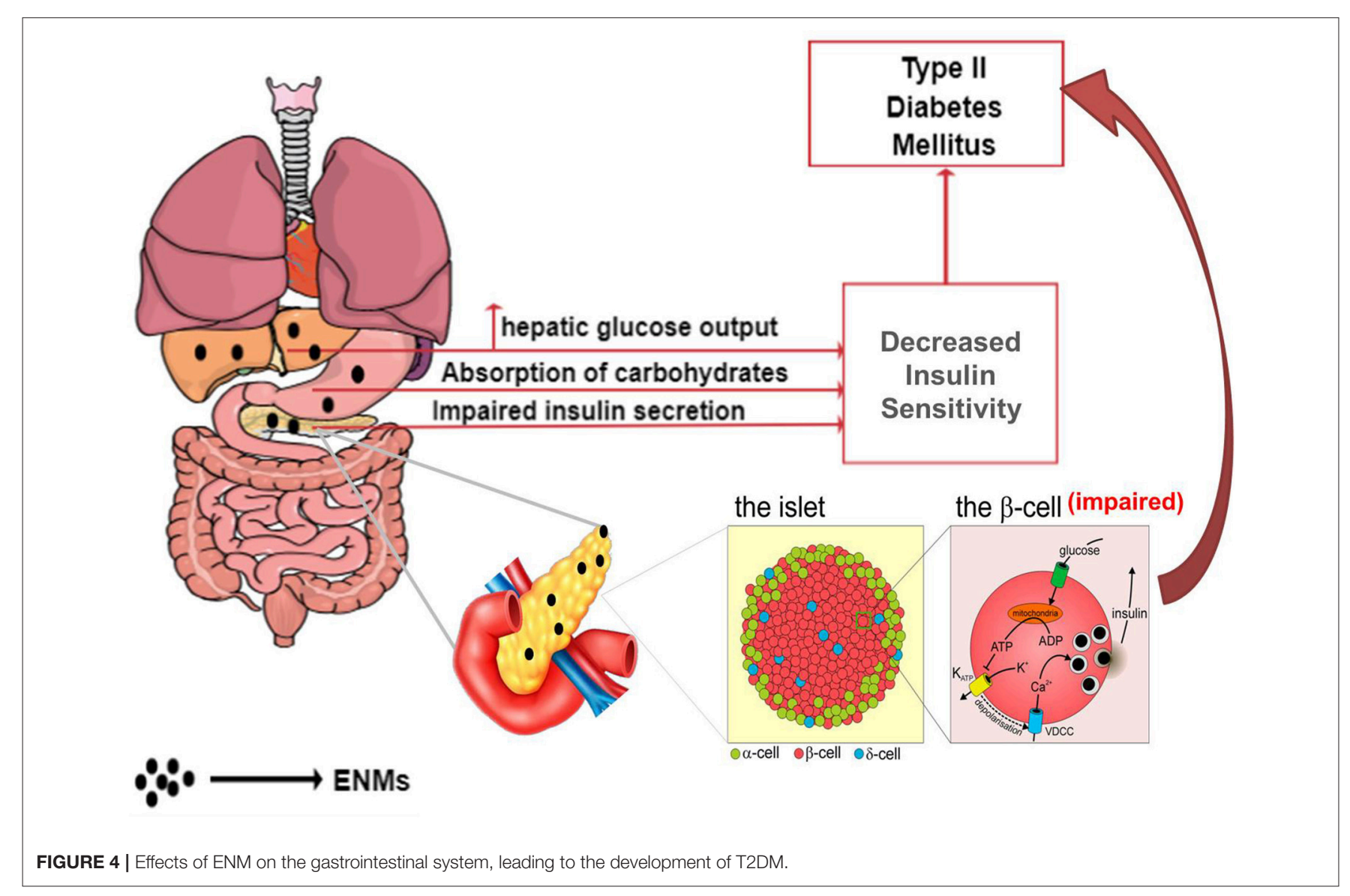

nucleus. The cellular metabolism is regulated by various proteins (e.g., protein kinase C), receptors (e.g., receptor tyrosine kinase) or expression of secondary messengers (e.g., cyclic AMP, calcium, and diacylglycerol). These components control the translocation and activation of glucose transporter proteins (primary effects of insulin) (133). ENMs can influence the signaling mechanism 
by interfering with the normal actions of cellular messengers (130, 134-137).

The effect of titanium oxide nanoparticles $\left(\mathrm{TiO}_{2}-\mathrm{NPs}\right)$ on insulin resistance in liver-derived cells was evaluated in a research study (138). Briefly, the dose-dependent action of $\mathrm{TiO}_{2}$-NPs on Fao cells (rat hepatoma) was investigated. The cells were exposed to various concentrations $(10,50,100$, and $200 \mu \mathrm{g} / \mathrm{mL}$ ) of $\mathrm{TiO}_{2}$-NPs. It was observed that treatment with $50-200 \mu \mathrm{g} / \mathrm{mL}$ of $\mathrm{TiO}_{2}$-NPs actuated insulin resistance by two mechanisms-directly affecting the hepatic cells to induce hepatic insulin resistance (Figure 2) and indirectly eliciting an inflammation response on macrophages (Figure 6) and hence releasing inflammatory cytokines such as Tumor Necrosis Factor $-\alpha$ (TNF- $\alpha)$ and Interleukins $-1 \alpha / \beta$ (IL- $1 \alpha / \beta)$. Administration of conditioned media form $\mathrm{TiO}_{2}$-NP-treated macrophages confirmed the activation of TNF- $\alpha$, IL-6, IL-8, IL$1 \alpha$, and IL-1 $\beta$. These inflammatory cytokines caused insulin resistance in Fao cells. In addition, it was observed that direct exposure of $\mathrm{TiO}_{2}-\mathrm{NPs}$ to hepatic cells triggered the activation of stress kinases-c-Jun N-terminal Kinases (JNK) and p38, which attenuated the phosphorylation of Insulin Receptor Substrate (IRS) $-1 / 2$, and Glycogen Synthase Kinase (GSK) $3 \beta$, and led to abnormal insulin signaling (Figure 5).

An 8-week study was conducted to evaluate the effects of chromium nanoparticles (CrNano) on the hormone and immune responses of rats under heat stress conditions (118). Four groups (with 20 individuals per group) of Sprague-Dawley (SD) rats were randomly assigned to different dietary treatments. The first group was offered a basal diet as a control. The second, third, and fourth groups received a basal diet supplemented with 150,300 , and $450 \mu \mathrm{g} / \mathrm{kg}$ of CrNano, respectively. The treatment groups were then studied for various parameters governing overall metabolism. Measurement of sera concentrations of hormones and immunoglobulins with respect to the control group showed a decreased concentration of insulin and an increased concentration of insulin-like growth factor I and immunoglobulin $\mathrm{G}$ in the serum.

The same research group conducted another 6-week study to evaluate the effects of seven different levels of dietary CrNano (0, $75,150,300,450,600$, and $1200 \mathrm{ppb} \mathrm{Cr}$ ) in SD rats (139). Seven groups with 10 individuals per group of SD rats were randomly assigned to different dietary treatments. The results indicated that an addition of 300 and $450 \mathrm{ppb}$ CrNano significantly decreased $(p<0.05)$ the serum insulin level. It was observed that the $\mathrm{Cr}$ contents in the liver and kidney were significantly increased $(p$ $<0.05$ ) by incremental dosage of CrNano from 150 to 1,200 ppb. The probable mechanism of reduction in peripheral insulin levels was ascribed to the activity of chromium in promoting hormone internalization into cells by increasing the membrane fluidity as explained by Evans and Bowman (140). This possibly led to altered insulin actions including binding of insulin to insulin receptors and the undesired interaction of insulin with various tissues such as adipose tissues and muscle tissues.

\section{Interaction With Estrogenic Receptors}

Estrogen receptors (ERs) expressed in adipose tissue, skeletal muscle, liver and pancreatic cells interact with estrogens and regulate metabolism. ER- $\alpha$ and ER- $\beta$ play an important role in the regulation of glucose homeostasis by modulation of insulin sensitivity (141) and pancreatic insulin secretion (142). Additionally, in order to alter insulin secretion, the estrogen receptors facilitate the action of estrogen via G-protein coupled membrane receptors (137). The available reports suggest an antagonistic action of EDENMs toward the estrogenic receptors $(127,143,144)$, which may lead to a decrease in insulin sensitivity and thereby alter glucose homeostasis.

The role of EDENMs in influencing estrogenic activity was demonstrated in a study where time-dependent $(1,3$, or $5 \mathrm{~h}$ ) treatment with $10 \mathrm{~nm}$ gold NPs to ovarian granulosa cells resulted in increased levels of estrogen (127). ERs have pathway modulation action via genomic and non-genomic approaches. While the genomic activity involves action of classical nuclear receptors to directly modulate the genes vital to homeostasis, the non-genomic route follows the use of kinases that activate signaling pathways resulting in the activation of ER pathway modulators. The increase in estrogen levels was suggested as indicative of the modulation of processes undergoing nuclear translocation, which might manipulate the normal gene expression for normal insulin signaling.

More evidence to support the endocrine-disrupting action of NMs was generated through illustrating the action of Cadmium Telluride Quantum Dots (CdTe QDs) (143). A dose-dependent study was carried out in uterine cells from female mice. The endocrine disrupting results were confirmed by a BrdU (BromodeoxyUridine) cell proliferation assay and a human ER 1 reporter assay for an assessment of ER activation.

\section{Inflammation as the Cause of Insulin Resistance}

In line with the ongoing research on the effect of ENMs on the immune system, research observations have established that the secretion of inflammatory cytokines by various cell types (Figure 6) has an impact on insulin resistance (126, 128, 145147). With their local and global action on different tissues, inflammatory cytokines have contributed to the development of insulin resistance and T2DM (146). The immune system recognizes ENMs as antigens and thus elicits an acute response. Under such circumstances, the adipose tissue upregulates the production of cytokines, which consequently leads to abrupt molecular signaling and the development of T2DM (148). Additionally, a substantial role of various ENMs in causing inflammation mediated toxicity has been previously reported $(138,149,150)$.

Evidence from in silico experiments has provided insights into the putative mechanistic underlying the toxic response of carbonbased ENMs that causes T2DM. The effects of introducing C60 fullerenes and carbon nanotubes in a living system were modeled in a computational analysis (151). Results demonstrated that carbon NMs could be recognized as pathogens by the Tolllike receptors that may elicit innate immune response. Such a theory was well supported by expression of inflammatory secretory proteins like interleukin IL-8 and chemokine monocyte chemoattractant protein (MCP1). In another study, direct exposure of ENMs, including nano-diamonds and nanoplatinum liquid, to human dendritic cells resulted in an enhanced 


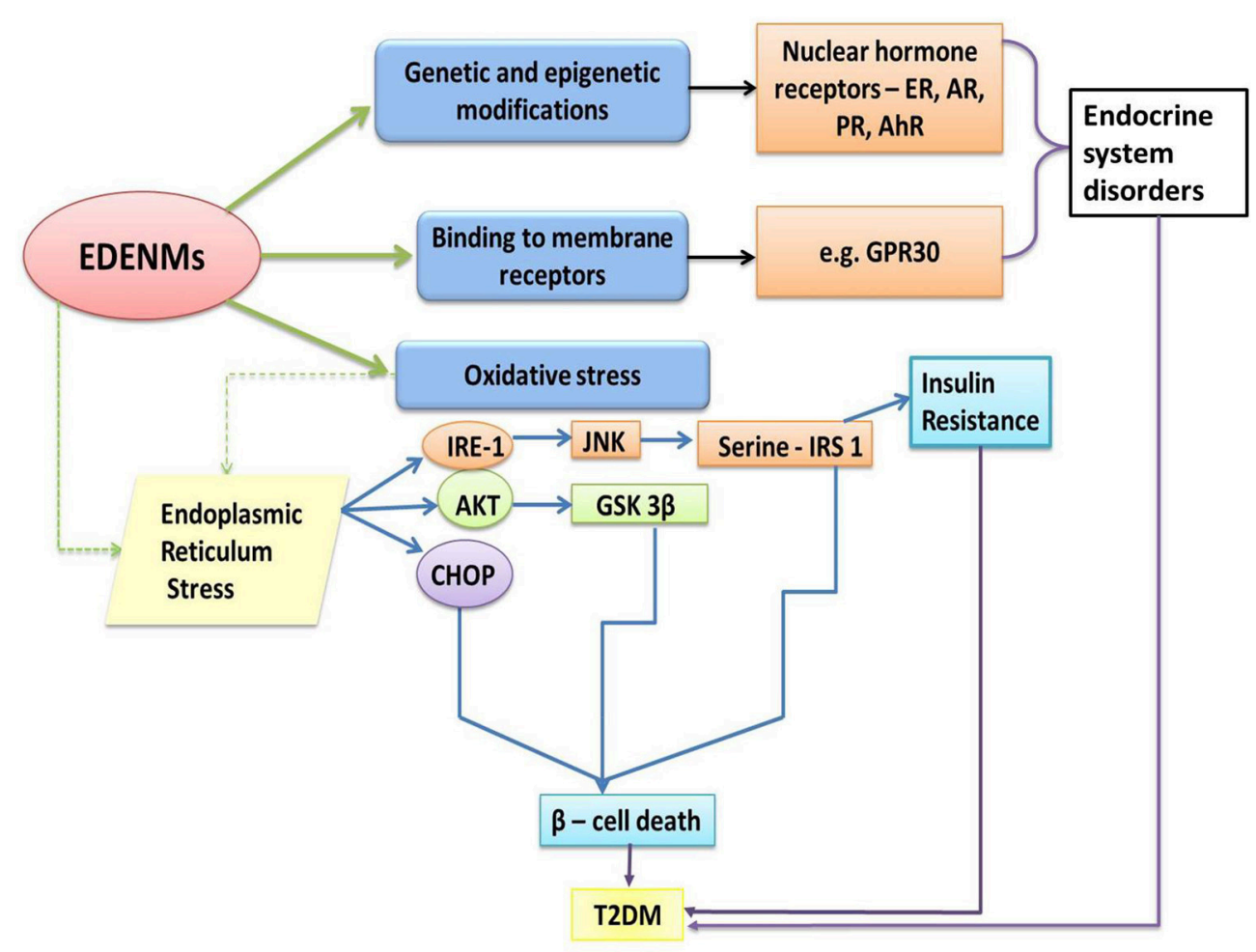

FIGURE 5 | Molecular pathways influenced by EDENM, leading to the development of T2DM. (EDENM, endocrine disrupting engineered nanomaterials; T2 DM, Type 2 Diabetes Mellitus; ER, estrogenic receptor; AR, androgenic receptor; PR, progesterone receptor; AhR, aryl hydrocarbon receptor; GPR30, G-protein-coupled receptor for estrogen; IRE-1, inositol-requiring enzyme 1; AKT, alpha serine/threonine kinase; CHOP, CCAAT-enhancer-binding protein homologous protein; JNK, c-Jun N-terminal kinase; GSK 3 $\beta$, Glycogen synthase kinase 3 beta; IRS-1, Insulin receptor substrate 1). (The green solid arrows show the direct effect of EDENM. The green dashed arrow shows one of the major consequent events later resulting in T2DM, as further described by the blue solid arrows. Black solid arrows point toward the involvement of various receptors resulting in endocrine system disorders. Purple solid arrows infer the T2DM occurrence via various pathways).

expression of IL-1 $\beta$, IL- 6 , and TNF- $\alpha$. These cytokines are known mediators for an inflammatory response (152).

Metallic ENMs were also studied to assess any associated immune response by exploring a variety of mechanisms. Many research groups have conducted various experiments to understand the mechanistic for the inflammatory action of gold nanoparticles (GNPs) (125-127, 153). In one study, two different sized GNPs, 10 and $50 \mathrm{~nm}$, were chosen to look for the enhancement of gene expression for cytokines IL-1 $\beta$, IL-6, and TNF- $\alpha$ by exposure to rat liver (146). The study also included experiments to understand the possibility of oxidative stress mediated damage to hepatic cells. The observations confirmed the generation of ROS in the presence of GNPs. These results clearly suggest that both the inflammation and oxidative stress related molecular pathways induced by ENMs play a significant role in the etiology of T2DM.

Another group investigated the combined effect of $\mathrm{ZnO}$ nanoparticle-mediated oxidative stress and immunogenic responses on immune cells. Immune cells, lymphocytes (activated memory and naïve) and monocytes, were assayed for the expression of (Interferon) IFN- $\gamma$, TNF- $\alpha$, and IL-12 upon treatment with $\mathrm{ZnO}$ nanoparticles of varying sizes $(4,8,13$ and
$20 \mathrm{~nm}$ ). It was observed that activated memory lymphocytes were the most robust against $\mathrm{ZnO}$ exposure, followed by naïve lymphocytes. Monocytes were the most susceptible of the three choices. The effect on immune cells was size-dependent, with the smallest $\mathrm{ZnO}$ particles contributing most to the generation of ROS and toxicity (154). Such findings are in line with the previously discussed roles of inflammation and oxidative stress in the etiology of T2DM.

Evidence to support the involvement of metallic ENMs in eliciting immune response was put forward by creating a novel platform, MIMIC (Modular Immune in vitro Construct, an artificial system imitating the human immune system). This provides a digitalized platform where the response of the immune system to an antigen can be modeled computationally. Also, it is more flexible and faster as compared to traditional cell or animal models. The study was modeled in a predictive immunological construct for assessment of the effect of nano$\mathrm{TiO}_{2}$ on the increase in the expression of IL- $1 \beta$, IL- 6 , and TNF$\alpha$. The results demonstrated an enhancement in the secretion of pro-inflammatory cytokines on $\mathrm{TiO}_{2}$ exposure. Additionally, the expression of co-stimulatory B7/CD28 on dendritic cells was observed, which suggested a putative action of T-cells against $\mathrm{TiO}_{2}$ nanoparticles (145). 

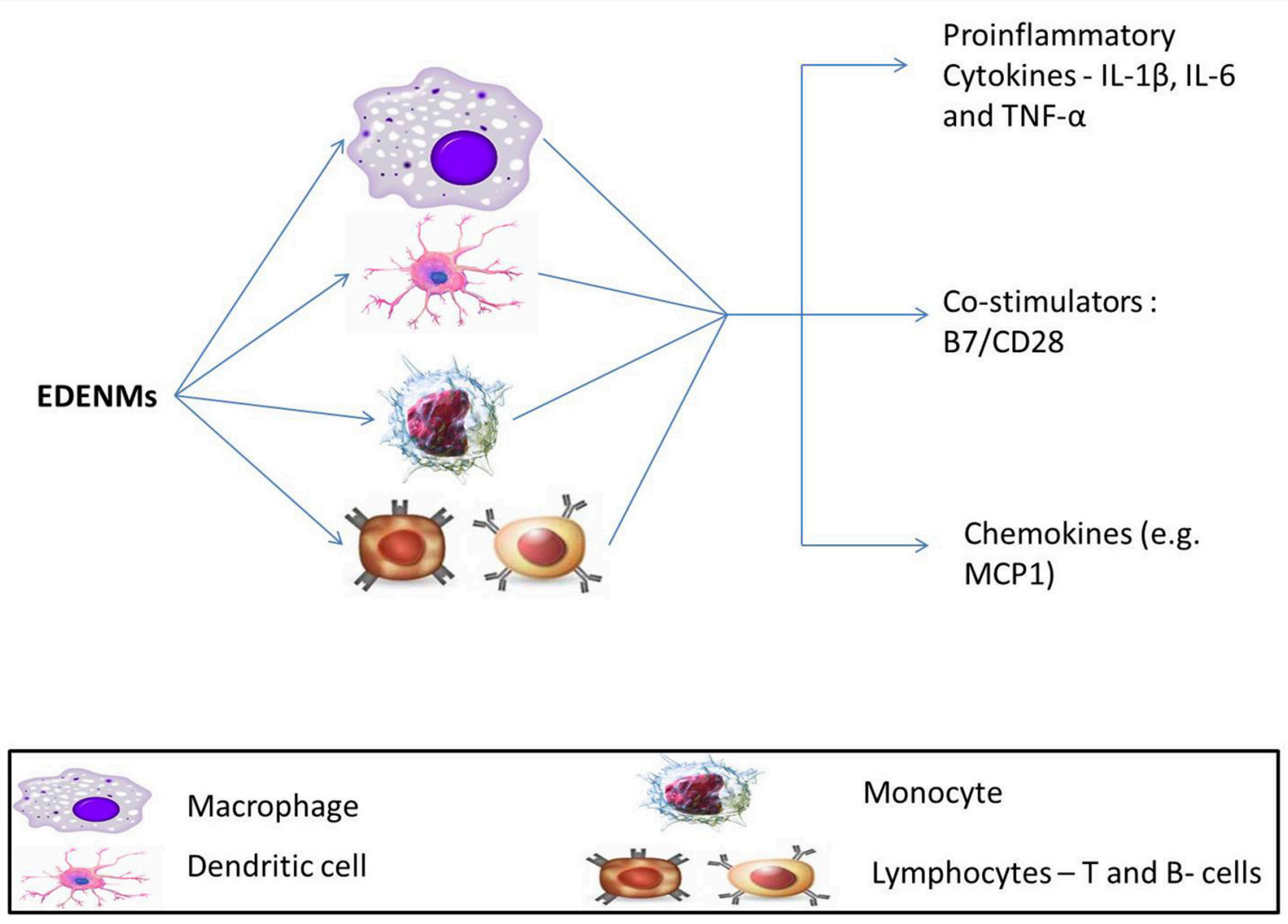

FIGURE 6 | Effect of EDENM on various immune cells resulting in enhancement of expression of various pro-inflammatory cytokines (Interleukins, IL-1 $\beta$, IL-6; TNF- $\alpha$, Tumor Necrosis Factor- $\alpha$ ), immunoglobulin superfamily members-B7/CD28 and chemokines (MCP-1, Monocyte chemoattractant protein-1).

The available clinical-epidemiological research studies have clearly illustrated the involvement of abrupt immune action and ROS in the occurrence of T2DM. This evidence points toward a predictable association of EDENM-dependent disruption of immune activities and ROS generation that consequently leads to $\mathrm{T} 2 \mathrm{DM}(155,156)$.

Much evidence can be found in literature that establishes a link between the involvement of the immune system and diabetes bridged via inflammation. As substantial evidence, an epidemiological study was conducted to correlate inflammation (as monitored by variations in CRP level) and the development of diabetes (155). Another study evaluated the association between the release of inflammatory cytokines and blood glucose levels. A many-fold increase in cytokine concentration occurred during the low-grade systemic inflammation (157). It was suggested that the accelerated concentrations of interleukins and TNF$\alpha$ may enable the migration of pro-inflammatory cytokines toward the insulin-signaling pathway. This may interfere with insulin signaling through phosphorylation of serine residues in insulin-receptor- substrate 1 (IRS 1) (158). Insulin-signaling may be blocked and insulin receptor (IR) stays dormant (159). In another epidemiological research, a diabetic Mexican-American population was studied for the effect of inflammation on the occurrence and prevalence of diabetes by testing for cytokines (IL-6, TNF- $\alpha$, IL-1 $\beta$, IL-8) and adipokine (adiponectin, resistin and leptin) levels in blood plasma. Increased plasma levels of these chemokines were found to be associated with increased blood glucose levels and T2DM (160). Several genetic association studies have suggested a role of polymorphism in the cytokine genes TNF- $\alpha$ and IL- 6 in the development of diabetes and its associated comorbidities, retinopathy (161) and nephropathy $(162,163)$. Researchers have conducted a meta-analysis to probe into associations between $-308 \mathrm{G}>\mathrm{A}$ (rs1800629) single nucleotide polymorphisms (SNP) in the TNF- $\alpha$ gene and T2DM (156). Another study reported significant association of genetic polymorphism in TNF- $\alpha$, with an increased risk of T2DM in the Han Chinese population (138).

It is evident from the discussion that EDENMs may influence the onset of T2DM by triggering inflammatory pathways. Additionally, the formerly discussed arguments with epidemiological evidence presents a direct link between inflammation and T2DM. Such proof can be used to probe more into inflammation-dependent pathogenesis of T2DM due the exposure to ENMs.

\section{Variations in Homeostatic Pathways}

The homeostatic pathways involved in energy metabolism influences the overall development of an organism (136). In the case of metabolic disorders, the normal flow of homeostatic pathway is affected and the regulation is breached 
(136, 164). The EDENMs intervene with the factors related to insulin signaling. These factors include various kinases, including phosphatidylinositol 3-kinase (PI3K), protein kinase $\mathrm{B}$, mammalian target of rapamycin (mTOR) and AMPK (AMPactivated protein kinase) which that tightly regulate sugar, lipid and amino acid homeostasis (164). This hampers the transduction of insulin signaling and results in diminished insulin action (165), which is followed by glucose metabolism malfunctions and development of T2DM.

In vitro studies have elucidated the action of metallic ENMs on homeostatic pathways. Findings from one study have established that heavy-metal NPs can elicit hyperglycemia (166). In another study, the influence of iron oxide $\left(\mathrm{Fe}_{2} \mathrm{O}_{3}\right)$ NPs exposure on the signaling mechanisms was studied in murine hepatocytes (50). In this dose-dependent study, $\mathrm{Fe}_{2} \mathrm{O}_{3} \mathrm{NPs}$ decreased the cell viability via the PI3K/Akt pathway. The exposure also resulted in a decrement of the intra-cellular antioxidant ability of hepatocytes. The study emphasized the role of exposure to $\mathrm{Fe}_{2} \mathrm{O}_{3}$ NPs (250 $\mathrm{g} / \mathrm{ml}$ ) in oxidative stress and apoptosis in the hepatic cells (167).

in vivo experiments have been carried out to explore the combined effect of ENM exposure and consequent abrupt functioning of oxidative stress and the homeostatic pathway on the endocrine system. Several in vivo studies have shown that the uptake of NMs has induced production of ROS (168). Physiological levels of ROS affected glucose metabolism pathways and insulin sensitivity (169). Moderate but longstanding oxidative stress has been found to be one of the major contributors in the onset of insulin resistance, and consequently T2DM (170). Oral introduction of $\mathrm{TiO}_{2}$ (anatase) nanoparticles to mice in a dose-dependent manner led to the accumulation of titanium in the liver, spleen, small intestine, kidney, and pancreas. Increased levels of titanium in these organs leads to insulin resistance, which was associated with increased phosphorylation of IRS1 (Ser307), JNK1, and p38 Mitogen activated protein kinase (MAPK), reduced phosphorylation of Akt (Ser473), and increased serum levels of TNF- $\alpha$ and IL- 6 in the liver. An increase in the generation of ROS observed in the study also suggests a role for ENM in the induction of oxidative stress (171).

\section{Impairment of $\beta$ Cells and Influence on Insulin Production}

The low doses of endocrine disruptors can alter the functioning of the pancreas by affecting the physiology of both insulin- and glucagon-secretory cells, which can further disrupt the regulation of glucose and lipid metabolism. As depicted in Figure 5, loss in $\beta$-cell mass is predominantly governed by the pathways involved in oxidative stress and endoplasmic reticulum stress. It is reported that oxidative stress is accounted by the generation of excess ROS and contributes to T2DM through $\beta$-cell death (172). It has also been extensively reviewed that endoplasmic reticulumstress plays a prominent role in causing apoptosis in pancreatic islets, resulting in $\beta$-cell death $(173,174)$.

A few metallic NMs have been shown to affect $\beta$-cells indirectly via influencing the kinases involved in transcriptional activation, followed by increased oxidative stress in the cells and finally apoptosis. In a research study carried out in macrophages, AuNPs of various sizes $(4,11,19,35$, and $45 \mathrm{~nm})$ suppressed NFK $\beta$ and JNK pathway activation. The process was observed due to de-methylation of CpG oligodeoxynucleotides (CpGODNs) motifs, making them act as immuno-stimulants (150). This effect was size dependent, with $4 \mathrm{~nm}$ AuNPs being the strongest suppressor. AuNPs potentially elicited an inflammatory response and induced oxidative stress as reviewed previously (128). Another study demonstrated the ROS generating capacity of Iron oxide $\left(\mathrm{Fe}_{3} \mathrm{O}_{4}\right)$ nanoparticles when $\mathrm{H}_{2} \mathrm{O}_{2}$ was used as the substrate (175). The hydroxyl free-radical generation reaction was biochemically similar to catalase and peroxidase action. It was inferred that the ROS may affect the pancreatic islet by JNK and NFK $\beta$ activation (176). Such observations supported the role of oxidative stress mediated inflammatory responses in $\beta$-cell damage, which may underlie the pathogenesis to T2DM.

Besides the above-discussed principle mechanisms, several unknown mechanisms underlying the development or pathogenesis of T2DM due to exposure to endocrine disrupters are also discussed in the available literature. The involvement of ultrafine particulate matter (key element of pollution) in the pathogenesis of T2DM is widely argued (52-56). Ultrafine particulate matter constitutes the ultrafine particles (UFPs), which are airborne particles with a thermodynamic/aerodynamic size of $<100 \mathrm{~nm}$. Diesel engines as well as automobiles, along with sand dust, fires, hot volcanic lava, and ocean spray along with combustion activities such as the burning of biomass or wood, generate and then release UFPs into the air. The mechanisms underlying the development of T2DM due to exposure to air pollutants have not been completely deciphered to date, however, an epidemiological study has been done to see the effect of ambient UFPs and nitrogen dioxide in a cohort of Canadian-born residents (177). The results clearly indicated that exposure to UFPs led to increased risk of incident hypertension (hazard ratio $=1.03 ; 95 \% \mathrm{CI}=1.02,1.04$ ) and diabetes (hazard ratio $=1.06 ; 95 \% \mathrm{CI}=1.05,1.08)$.

\section{CONCLUSIONS AND PERSPECTIVES}

Evidence suggesting a role of EDENM exposure in the pathogenesis of T2DM is gradually emerging, but a comprehensive understanding of a wide range of nanomaterials and their effect on candidate gene pathways and other causal factors involved in T2DM remain to be completely deciphered. The fact that ENM can disrupt the endocrine system, which may eventually lead to T2DM, has gathered support from several in vitro, in vivo, and epidemiological studies. Altered glucose metabolism through various molecular mechanisms including insulin resistance, decreased insulin sensitivity, induction of oxidative stress pathways, and altered homeostasis have been reported by numerous laboratory studies that examined the effect of EDENM exposures. On the other hand, a few studies also report a contrasting effect of the same EDENM on T2DM related molecules. Many research groups have come up with a safer application of ENMs by illustrating their ability to work as 
TABLE 1 | Different categories of ENM used in therapeutics against T2DM.

\begin{tabular}{|c|c|c|c|}
\hline Type & Application & Study system & References \\
\hline \multicolumn{4}{|l|}{ NON-METALLIC ENM } \\
\hline $\begin{array}{l}\text { PEG-b-PLGA-biodegradable Polyethylene glycol and } \\
\text { Poly (lactic-co-glycolic acid) copolymer (PEG-b-PLGA) } \\
\text { Based cationic lipid-assisted nanoparticles (clans) }\end{array}$ & Anti-inflammatory action & Diet-induced type 2 diabetes mice & $(183)$ \\
\hline Chitosan & $\begin{array}{l}\text { Gene delivery for Glucagon like peptide } 1 \\
\text { (GLP-1), dipeptydil peptidase IV (DPP-IV } \\
\text { resistant GLP-1 analogs) and siRNA targeting } \\
\text { against DPP-IV }\end{array}$ & HT-29, HepG2, and Caco-2 cell lines & $(184)$ \\
\hline Insulin-loaded nano-carriers & Transdermal delivery of insulin & $\begin{array}{l}\text { Streptozotocin-diabetic male Wistar } \\
\text { rats }\end{array}$ & $(185)$ \\
\hline Alginic acid nanoparticles containing insulin & Sublingual delivery of insulin & $\begin{array}{l}\text { Streptozotocin-induced diabetic male } \\
\text { Wistar rats }\end{array}$ & $(186)$ \\
\hline $\begin{array}{l}\text { Insulin-containing } \\
\text { Polyethylene imine-based nanoparticles }\end{array}$ & Insulin-delivery & Sprague Dawley rats & $(187)$ \\
\hline $\begin{array}{l}\text { PLGA as the carrier to prepare recombinant human } \\
\text { epidermal growth factor (rhEGF) nanoparticles }\end{array}$ & Diabetic wound healing & Diabetic rats & $(188)$ \\
\hline $\begin{array}{l}\text { Insulin encapsulated in polyalkylcyanoacrylate } \\
\text { nanocapsules }\end{array}$ & Hypoglycemia effect & Diabetic rats & $(189)$ \\
\hline $\begin{array}{l}\text { Nanoparticles from dextran, poly ( } \alpha-1,6 \text { glucose), } \\
\text { physically cross-linked with the tetra functional } \\
\text { glucose-binding protein, Con A }\end{array}$ & Controlled delivery of insulin & In vitro studies & $(190)$ \\
\hline Injectable insulin nano-particles & Insulin delivery & $\begin{array}{l}\text { Subcutaneous administration in } \\
\text { diabetic mice }\end{array}$ & $(191)$ \\
\hline \multicolumn{4}{|l|}{ BIOSYNTHESIZED ENM } \\
\hline $\begin{array}{l}\text { Eysenhardtia polystachya-loaded silver nanoparticles } \\
\text { (EP/AgNPs) }\end{array}$ & Antidiabetic activity & $\begin{array}{l}\text { Pancreatic } \beta \text { cells, INS-1 cells, and } \\
\text { Danio rerio }\end{array}$ & $(180)$ \\
\hline $\begin{array}{l}\text { Gold nanoparticles (AuNPs) synthesized using Gymnema } \\
\text { sylvestre R. Br Plant extract }\end{array}$ & Antidiabetic activity & Wistar albino rats & $(182)$ \\
\hline $\begin{array}{l}\text { Gold nanoparticles (AuNPs) synthesized using Cassia } \\
\text { auriculata plant extract }\end{array}$ & Increasing plasma insulin activity & Alloxan induced albino rats & $(181)$ \\
\hline \multicolumn{4}{|l|}{ METALLIC ENM } \\
\hline Insulin-coated gold nanoparticles (INS-GNPs) & $\begin{array}{l}\text { For controlled and prolonged glucose } \\
\text { regulation was reported }\end{array}$ & $\begin{array}{l}\text { Intravenous and subcutaneous } \\
\text { administration to diabetic mouse } \\
\text { model }\end{array}$ & $(192)$ \\
\hline Gold NPs and aspartic acid-capped gold nanoparticles & Insulin delivery & Diabetic Wistar rats & $(193)$ \\
\hline Gold nanoparticles and Dextran-insulin conjugates & Insulin delivery & Mouse 3T3-L1 cell line & $(194)$ \\
\hline Mesoporous silica nanoparticles (MSNs) & $\begin{array}{l}\text { Gluconic acid-modified insulin (G-Ins) proteins } \\
\text { labeled with fluorescein isothiocyanate } \\
\text { (FITC-G-Ins) were immobilized on the exterior } \\
\text { surface of MSN which served as caps to } \\
\text { encapsulate CAMP molecules inside the } \\
\text { mesopores of MSN }\end{array}$ & $\mathrm{RIN-5F}$ & $(194,195)$ \\
\hline Selenium nanoparticles (SeNPs) & $\begin{array}{l}\text { Oral delivery of insulin to enhance the } \\
\text { antidiabetic effect }\end{array}$ & $\begin{array}{l}\text { Normal (Sprague-Dawley, SD) and } \\
\text { type II DM (Goto-Kakizaki, GK) rats }\end{array}$ & $(196)$ \\
\hline
\end{tabular}

therapeutics. Particularly, some of the biologically synthesized ENMs $(178,179)$ were found to possess therapeutic potential against T2DM (180-182). Other non-metallic and metallic NMs for similar applications are also reported (Table 1).

In an interesting study, an increase in cell viability, $\mathrm{ATP} / \mathrm{ADP}$ ratio and secretion of insulin in response to glucose stimuli in the isolated pancreatic islets when treated with metallic nanoparticles prepared from cerium oxide $\left(\mathrm{CeO}_{2}\right.$ $\mathrm{NPs}$ ) at a concentration of $100 \mathrm{nmol} / \mathrm{L}$, either alone or in combination with $30 \mathrm{nmol} / \mathrm{L}$ sodium selenite, was reported (197). These findings could possibly be ascribed to the anti-oxidant potential of $\mathrm{CeO}_{2}$-NPs, which may exert a different effect on the insulin release. In a similar study, the effect of zinc oxide nanoparticles $(\mathrm{ZON})$ on oxidative stress-mediated pancreatic $\beta$-cell death was investigated in rats (RIN5f). The cellular levels of antioxidant factors and the rate of apoptosis were assessed in correlation with $\mathrm{ZON}$ uptake. RIN5f cell treatment with $\mathrm{ZON}$ (30 and $100 \mu \mathrm{g} / \mathrm{ml}$ ) resulted in cytotoxicity, oxidative stress and apoptosis. In contrast, the sub-cytotoxic concentrations $(1,3,10 \mu \mathrm{g} / \mathrm{ml})$ protected RIN5f cells from hydrogen peroxide $\left(\mathrm{H}_{2} \mathrm{O}_{2}\right)$-induced oxidative stress by the reducing the cellular levels of ROS, increased SOD activity 
and GSH, and reduced cell death (198). The findings reported in the above-mentioned studies indicated that nanomaterialtype and size dependencies on the associated cellular toxicity are not precisely explored. An incomplete characterization of ENM may underlie discrepancies observed in available scientific reports. Confusion created from such incomplete explorations demands for the development of a common understanding in the area of ENM characteristics (shape, size, surface area, mass concentration, or a combination of these), which should be a prerequisite to toxic effect determination. This broadens the scope of research to particularly define physicochemical properties of ENM for their sustainable bio-medical applications. Considering this, ENMs for vital bio-medical, pharmaceutical, agricultural, and environmental applications are required to be well characterized for their uptake to various cell/ tissue types, interaction with cellular organelles and cell mechanistic aspects within the intracellular environment (199).

Since in vitro systems do not necessarily mimic the human system, results obtained from such experiments need to be replicated through in vivo studies conducted in different model animals. Additionally, in vivo studies that address potential effects of EDENM on the development of T2DM at a large scale such as a population, a community, or an ecosystem with sufficient power are necessarily required. Further, most of the in vivo studies have been conducted on small rodents, specifically rats, mice and hamsters, which may not be optimum for studying the long-term toxic effects of nanomaterial and makes it difficult to extrapolate the observed results to humans. Experiments by including other model systems, which are more closely related to human systems, like Danio rerio, Daphnia magna, and Caenorhabditis elegans need to be conducted in more numbers.

\section{REFERENCES}

1. Chennupati Jagadish AB. Nanoscience: thinking big, working small. In: Chennupati Jagadish $\mathrm{AB}$, editor. Technology and the Future. Acton: Australian Academy of Science (2015). Available online at: https://www. science.org.au/curious/nanoscience

2. Schmid G, Fenske D. Metal Clusters and Nanoparticles. London: The Royal Society (2010).

3. Pietroiusti A, Stockmann-Juvala H, Lucaroni F, Savolainen K. Nanomaterial exposure, toxicity, and impact on human health. Wiley Interdiscip Rev Nanomed Nanobiotechnol. (2018) 10:e1513. doi: 10.1002/wnan.1513

4. Iavicoli I, Fontana L, Pingue P, Todea AM, Asbach C. Assessment of occupational exposure to engineered nanomaterials in research laboratories using personal monitors. Sci Total Env. (2018) 627:689-702. doi: 10.1016/j.scitotenv.2018.01.260

5. Guttenberg M, Bezerra L, Neu-Baker NM, del Pilar Sosa Idelchik M, Elder A, Oberdörster G, et al. Biodistribution of inhaled metal oxide nanoparticles mimicking occupational exposure: a preliminary investigation using enhanced darkfield microscopy. J Biophot. (2016) 9:98793. doi: 10.1002/jbio. 201600125

6. Catalán J, Ilves M, Järventaus H, Hannukainen KS, Kontturi E, Vanhala E, et al. Genotoxic and immunotoxic effects of cellulose nanocrystals in vitro. Environ Mol Mutagen. (2015) 56:171-82. doi: 10.1002/em.21913

7. Palomäki J, Välimäki E, Sund J, Vippola M, Clausen PA, Jensen KA, et al. Long, needle-like carbon nanotubes and asbestos activate the NLRP3 inflammasome through a similar mechanism. ACS Nano (2011) 5:6861-70. doi: $10.1021 / \mathrm{nn} 200595 \mathrm{c}$
Furthermore, pre-clinical in vitro studies, such as those using blood samples from a control population, can also be conducted for impact-assessment of EDENMs (200). Additional support to the candidate mechanisms underlying EDENM mediated T2DM and identification of novel pathways can be achieved through the application of the "-omics" approach, which at present is virtually lacking. Also, developing high-throughput pre-screening (HTPS) and quantitative structure-activity relationship (QSAR) methods for in silico screening and prediction would be extremely important to comprehend the effect of EDENM (201).

We emphasize the importance of research on safety aspect of ENMs, which would minimize the uncertainties regarding the health and environmental issues surrounding these advancematerials and help in the development of safe applications of nanotechnologies.

\section{AUTHOR CONTRIBUTIONS}

PS was the Principal Scientist, involved in conceptualization of the review, study design, data analyses, data compilation, manuscript writing, critical inputs, and finalization of the manuscript. AP contributed toward data analyses, data compilation, manuscript writing, critical inputs, and finalization of the manuscript. SG was involved in data compilation and manuscript writing. All authors have read and approved the final manuscript.

\section{ACKNOWLEDGMENTS}

The research activities of the authors are supported by the TERIDeakin Nanobiotechnology Centre, Gurugram, India.

8. Rossi EM, Pylkkänen L, Koivisto AJ, Nykäsenoja H, Wolff H, Savolainen $\mathrm{K}$, et al. Inhalation exposure to nanosized and fine TiO 2 particles inhibits features of allergic asthma in a murine model. Part Fibre Toxicol. (2010) 7:35. doi: 10.1186/1743-8977-7-35

9. Kreyling WG, Semmler-Behnke M, Seitz J, Scymczak W, Wenk A, Mayer P, et al. Size dependence of the translocation of inhaled iridium and carbon nanoparticle aggregates from the lung of rats to the blood and secondary target organs. Inhalat Toxicol. (2009) 21:55-60. doi: 10.1080/08958370902942517

10. Nel A, Xia T, Mädler L, Li N. Toxic potential of materials at the nanolevel. Science (2006) 311:622-7. doi: 10.1126/science.11 14397

11. Zhao F, Zhao Y, Liu Y, Chang X, Chen C, Zhao Y. Cellular uptake, intracellular trafficking, and cytotoxicity of nanomaterials. Small (2011) 7:1322-37. doi: 10.1002/smll.201100001

12. Rosenkranz P, Fernández-Cruz $M$, Conde E, Ramírez-Fernández M, Flores J, Fernández M, et al. Effects of cerium oxide nanoparticles to fish and mammalian cell lines: an assessment of cytotoxicity and methodology. Toxicol Vitro (2012) 26:888-96. doi: 10.1016/j.tiv.2012. 04.019

13. Komatsu T, Tabata M, Kubo-Irie M, Shimizu T, Suzuki KI, Nihei Y, et al. The effects of nanoparticles on mouse testis Leydig cells in vitro. Toxicol Vitro (2008) 22:1825-31. doi: 10.1016/j.tiv.2008.08.009

14. Bai Y, Zhang Y, Zhang J, Mu Q, Zhang W, Butch ER, et al. Repeated administrations of carbon nanotubes in male mice cause reversible testis damage without affecting fertility. Nat Nanotechnol. (2010) 5:683. doi: $10.1038 /$ nnano. 2010.153 
15. Damstra BST, Bergman A, Kavlock RJ, van der Kraak G. Global Assessment of the State-of-the-Science of Endocrine Disruptors. Geneva: World Health Organization (2002).

16. Mnif W, Hassine IHA, Bouaziz A, Bartegi A, Thomas O, Roig B. Effect of endocrine disruptor pesticides: a review. Int J Env Res Public Health (2011) 8:2265-303. doi: 10.3390/ijerph8062265

17. Combarnous Y, Endocrine Disruptor Compounds (EDCs) and agriculture: the case of pesticides. Comp Rendus Biol. (2017) 340:406-9. doi: 10.1016/j.crvi.2017.07.009

18. Diamanti-Kandarakis E, Bourguignon JP, Giudice LC, Hauser R, Prins GS, Soto AM, et al. Endocrine-disrupting chemicals: an endocrine society scientific statement. Endocr Rev. (2009) 30:293-342. doi: 10.1210/er.2009-0002

19. Rudel RA, Perovich LJ. Endocrine disrupting chemicals in indoor and outdoor air. Atmosph Environ. (2009) 43:170-81. doi: 10.1016/j.atmosenv.2008.09.025

20. Nicolopoulou-Stamati P, Hens L, Sasco AJ. Cosmetics as endocrine disruptors: are they a health risk? Rev Endocr Metab Dis. (2015) 16:373-83. doi: 10.1007/s11154-016-9329-4

21. Knez J. Endocrine-disrupting chemicals and male reproductive health. Reprod Bio Med Online (2013) 26:440-8. doi: 10.1016/j.rbmo.2013.02.005

22. Zlatnik G. Endocrine-disrupting chemicals and reproductive health. $J$ Midwifery Wom Health (2016) 61:442-55. doi: 10.1111/jmwh.12500

23. Zama AM, Bhurke A, Uzumcu M. Effects of endocrine-disrupting chemicals on female reproductive health. Open Biotechnol. J. (2016) 10:54-75. doi: 10.2174/1874070701610010054

24. Jeng HA. Exposure to endocrine disrupting chemicals and male reproductive health. Front Public Health (2014) 2:55. doi: 10.3389/fpubh.2014.00055

25. Marques-Pinto A, Carvalho D. Human infertility: are endocrine disruptors to blame? Endocr Connec. (2013) 2:R15-29. doi: 10.1530/EC-13-0036

26. Teitelbaum SL, Belpoggi F, Reinlib L. Advancing research on endocrine disrupting chemicals in breast cancer: expert panel recommendations. Reproduc Toxicol. (2015) 54:141-7. doi: 10.1016/j.reprotox.2014.12.015

27. Soto AM, Sonnenschein C. Environmental causes of cancer: endocrine disruptors as carcinogens. Nat Rev Endocrinol. (2010) 6:363-70. doi: $10.1038 /$ nrendo. 2010.87

28. Morgan M, Deoraj A, Felty Q, Roy D. Environmental estrogen-like endocrine disrupting chemicals and breast cancer. Mol Cell Endocrinol. (2017) 457:89-102. doi: 10.1016/j.mce.2016.10.003

29. Abdel-Rahman W, Moustafa Y, O Ahmed B, Mostafa R. Endocrine disruptors and breast cancer risk - time to consider the environment. Asian Pacific J Cancer (2012) 13:5937. doi: 10.7314/APJCP.2012.13.12.5937

30. Rachon D. Endocrine disrupting chemicals (EDCs) and female cancer: informing the patients. Rev Endocr Metab Dis. (2015) 16:359-64. doi: 10.1007/s11154-016-9332-9

31. Greet S, Elly DH, Willem D, Nik VL, Marike L. Endocrine disruptors and abnormalities of pubertal development. Basic Clin Pharmac Toxicol. (2008) 102:168-75. doi: 10.1111/j.1742-7843.2007.00180.x

32. Lee HR, Jeung EB, Cho MH, Kim TH, Leung PCK, Choi KC. Molecular mechanism(s) of endocrine-disrupting chemicals and their potent oestrogenicity in diverse cells and tissues that express oestrogen receptors. $J$ Cell Mol Med. (2013) 17:1-11. doi: 10.1111/j.1582-4934.2012.01649.x

33. Shahidehnia M. Epigenetic effects of endocrine disrupting chemicals. $J$ Environ Anal Toxicol. (2016) 6:381. doi: 10.4172/2161-0525.1000381

34. Colborn T. Neurodevelopment and endocrine disruption. Environ Health Perspect. (2004) 112:944-9. doi: 10.1289/ehp.6601

35. Meeker JD. Exposure to environmental endocrine disruptors and child development. Arch Pediatr Adolesc Med. (2012) 166:E1-7. doi: 10.1001/archpediatrics.2012.241

36. Pinson A, Bourguignon JP, Parent AS. Exposure to endocrine disrupting chemicals and neurodevelopmental alterations. Andrology (2016) 4:706-22. doi: 10.1111/andr.12211

37. Xu H, Yang M, Qiu W, Pan C, Wu M. The impact of endocrine-disrupting chemicals on oxidative stress and innate immune response in zebrafish embryos. Environ Toxicol Chem. (2013) 32:1793-9. doi: 10.1002/etc.2245

38. Rogers JA, Metz L, Yong VW. Review: endocrine disrupting chemicals and immune responses: a focus on bisphenol-A and its potential mechanisms. Mol Immunol. (2013) 53:421-30. doi: 10.1016/j.molimm.2012.09.013
39. Kuo $\mathrm{CH}$, Yang $\mathrm{SN}$, Kuo PL, Hung $\mathrm{CH}$. Immunomodulatory effects of environmental endocrine disrupting chemicals. Kaohsiung J Med Sci. (2012) 28:S37-42. doi: 10.1016/j.kjms.2012. 05.008

40. Ferin J. Pulmonary retention and clearance of particles. Toxicol Lett. (1994) 72:121-5. doi: 10.1016/0378-4274(94)90018-3

41. Borm PJ, Schins RP, Albrecht C. Inhaled particles and lung cancer, part B: paradigms and risk assessment. Int J Cancer (2004) 110:3-14. doi: $10.1002 / \mathrm{ijc} .20064$

42. Oberdörster G, Ferin J, Lehnert BE. Correlation between particle size, in vivo particle persistence, and lung injury. Environ Health Perspect. (1994) 102:173-9.

43. Dasenbrock C, Peters L, Creutzenberg O, Heinrich U. The carcinogenic potency of carbon particles with and without PAH after repeated intratracheal administration in the rat. Toxicol Lett. (1996) 88:15-21. doi: 10.1016/0378-4274(96)03712-5

44. Driscoll KE, Carter JM, Howard BW, Hassenbein DG, Pepelko W, Baggs RB, et al. Pulmonary inflammatory, chemokine, and mutagenic responses in rats after subchronic inhalation of carbon black. Toxicol Appl Pharmacol. (1996) 136:372-80. doi: 10.1006/taap.1996.0045

45. Nikula K, Snipes M, Barr E, Griffith W, Henderson R, Mauderly J. Comparative pulmonary toxicities and carcinogenicities of chronically inhaled diesel exhaust and carbon black in F344 rats. Fundam Appl Toxicol. (1995) 25:80-94. doi: 10.1006/faat.1995.1042

46. Casals-Casas C, Desvergne B. Endocrine disruptors: from endocrine to metabolic disruption. Annu Rev Physiol. (2011) 73:135-62. doi: 10.1146/annurev-physiol-012110-142200

47. Purdel C, Ilie M, Margina D. The involvement of environmental endocrinedisrupting chemicals in type 2 Diabetes Mellitus Development. In: Croniger C. editor. Treatment of Type 2 Diabetes. London: IntechOpen (2015) 219-50. doi: 10.5772/59110

48. Piemonte L. About Diabetes. International Diabetes Federation (2018).

49. Chevalier N, Fenichel P. Endocrine disruptors: new players in the pathophysiology of type 2 diabetes? Diabetes Metab. (2015) 41:107-15. doi: 10.1016/j.diabet.2014.09.005

50. Savolainen K, Alenius H, Norppa H, Pylkkänen L, Tuomi T, Kasper G. Risk assessment of engineered nanomaterials and nanotechnologies-a review. Toxicology (2010) 269:92-104. doi: 10.1016/j.tox.2010.01.013

51. Valsami-Jones E, Lynch I. How safe are nanomaterials? Science (2015) 350:388-9. doi: 10.1126/science.aad0768

52. Taylor DA. Dust in the wind. Environ Health Perspect. (2002) 110:A80-7. doi: 10.1289/ehp.110-a80

53. Dikio D, Bixa N. Carbon nanotubes synthesis by catalytic decomposition of ethyne using Fe/Ni catalyst on aluminium oxide support. Int J Appl Chem. (2011) 7:35-42.

54. Shooto DN, Dikio ED. Morphological characterization of soot from the combustion of candle wax. Int. J. Electrochem. Sci. (2011) 6:1269-76.

55. Srilatha K, Bhagawan D, Shiva Kumar S, Himabindu V. Sustainable fuel production by thermocatalytic decomposition of methane - A review. South Afr J Chem Eng. (2017) 24:156-67. doi: 10.1016/j.sajce.2017. 10.002

56. Kumar R, Bharagava RN, Kumar M, Singh S, Kumar G. Enhanced biodegradation of mobil oil hydrocarbons by biosurfactant producing bacterial consortium in wheat and mustard rhizosphere. J Petrol Environ Biotechnol. (2013) 4:158. doi: 10.4172/2157-7463.10 00158

57. Hu Q, Li H, Wang L, Gu H, Fan C. DNA nanotechnology-enabled drug delivery systems. Chem Rev. (2018). doi: 10.1021/acs.chemrev.7b00663. [Epub ahead of print].

58. Sahoo SK, Misra R, Parveen S. Nanoparticles: a boon to drug delivery, therapeutics, diagnostics and imaging. Nanomed Cancer (2017) 73-124. doi: 10.1016/j.nano.2011.05.016

59. Xu R, Ferrari M, Shen H. A pro-nanodrug with intratumoral reconstitution and intracellular delivery beyond therapy-resistance molecular pumps. In: Proceeding of AACR Annual Meeting. Washington, DC (2017).

60. Xu S, Zhu X, Huang W, Zhou Y, Yan D. Supramolecular cisplatinvorinostat nanodrug for overcoming drug resistance in cancer synergistic 
therapy. J Contr Release (2017) 266:36-46. doi: 10.1016/j.jconrel.2017. 09.007

61. Ji C, Gao Q, Dong X, Yin W, Gu Z, Gan Z, et al. A size-reducible nanodrug with an aggregation-enhanced photodynamic effect for deep chemo-photodynamic therapy. Angew Chem Int Ed Engl. (2018) 57:1138488. doi: 10.1002/anie.201807602

62. Rahi A, Karimian K, Heli H. Nanostructured materials in electroanalysis of pharmaceuticals. Analy Biochem. (2016) 497:39-47. doi: 10.1016/j.ab.2015.12.018

63. Sridhar R, Ramakrishna S. Electrosprayed nanoparticles for drug delivery and pharmaceutical applications. Biomatter (2013) 3:e24281. doi: 10.4161/biom. 24281

64. Yin J, Wang Y, Gilbertson LM. Opportunities to advance sustainable design of nano-enabled agriculture identified through a literature review. Environ Sci. Nano (2018) 5:11-26. doi: 10.1039/C7EN00766C

65. Kah M, Kookana RS, Gogos A, Bucheli TD. A critical evaluation of nanopesticides and nanofertilizers against their conventional analogues. Nat Nanotechnol. (2018) 13:677-684. doi: 10.1038/s41565-018-0131-1

66. Srivastava AK, Dev A, Karmakar S. Nanosensors and nanobiosensors in food and agriculture. Environ Chem Lett. (2018) 1:161-82. doi: 10.1007/s10311-017-0674-7

67. Mueller NC, Nowack B. Exposure modeling of engineered nanoparticles in the environment. Environ Sci Technol. (2008) 42:4447-53. doi: $10.1021 /$ es7029637

68. Gottschalk F, Nowack B. The release of engineered nanomaterials to the environment. J Environ Monit. (2011) 13:1145-55. doi: 10.1039/c0em 00547a

69. Gottschalk F, Sonderer T, Scholz RW, Nowack B. Possibilities and limitations of modeling environmental exposure to engineered nanomaterials by probabilistic material flow analysis. Environ Toxicol Chem. (2010) 29:103648. doi: $10.1002 /$ etc. 135

70. Oberdorster G. Pulmonary effects of inhaled ultrafine particles. Int Arch Occupat Environ Health (2001) 74:1-8. doi: 10.1007/s004200000185

71. Roduner E. Size matters: why nanomaterials are different. Chem Soc Rev. (2006) 35:583-92. doi: 10.1039/b502142c

72. Kouwenhoven LP, Austing D, Tarucha S. Few-electron quantum dots. Rep Prog Phys. (2001) 64:701. doi: 10.1088/0034-4885/64/6/201

73. Hoet $\mathrm{PH}$, Brüske-Hohlfeld I, Salata OV. Nanoparticles-known and unknown health risks. J Nanobiotechnol. (2004) 2:12. doi: 10.1186/1477-3155-2-12

74. Takenaka S, Karg E, Roth C, Schulz H, Ziesenis A, Heinzmann $\mathrm{U}$, et al. Pulmonary and systemic distribution of inhaled ultrafine silver particles in rats. Environ Health Perspect. (2001) 109:547-51. doi: 10.1289/ehp.01109s4547

75. Xia T, Kovochich M, Brant J, Hotze M, Sempf J, Oberley T, et al. Comparison of the abilities of ambient and manufactured nanoparticles to induce cellular toxicity according to an oxidative stress paradigm. Nano Lett. (2006) 6:1794807. doi: $10.1021 / \mathrm{nl} 061025 \mathrm{k}$

76. Garcia-Garcia E, Andrieux K, Gil S, Kim HR, Le Doan T, Desmaële $D$, et al. A methodology to study intracellular distribution of nanoparticles in brain endothelial cells. Int J Pharmac. (2005) 298:310-4. doi: 10.1016/j.ijpharm.2005.03.030

77. Gurr JR, Wang AS, Chen CH, Jan KY. Ultrafine titanium dioxide particles in the absence of photoactivation can induce oxidative damage to human bronchial epithelial cells. Toxicology (2005) 213:66-73. doi: 10.1016/j.tox.2005.05.007

78. Singal M, Finkelstein JN. Amorphous silica particles promote inflammatory gene expression through the redox sensitive transcription factor, AP-1, in alveolar epithelial cells. Exp Lung Res. (2005) 31:581-97. doi: 10.1080/019021490951504

79. Kato T, Yashiro T, Murata Y, Herbert DC, Oshikawa K, Bando M, et al. Evidence that exogenous substances can be phagocytized by alveolar epithelial cells and transported into blood capillaries. Cell Tissue Res. (2003) 311:47-51. doi: 10.1007/s00441-002-0647-3

80. Hopwood D, Spiers E, Ross P, Anderson J, McCullough J, Murray F. Endocytosis of fluorescent microspheres by human oesophageal epithelial cells: comparison between normal and inflamed tissue. Gut (1995) 37:598602. doi: $10.1136 /$ gut.37.5.598
81. Rothen-Rutishauser BM, Schürch S, Haenni B, Kapp N, Gehr P. Interaction of fine particles and nanoparticles with red blood cells visualized with advanced microscopic techniques. Environ Sci Technol. (2006) 40:4353-9. doi: $10.1021 /$ es0522635

82. Peters A, Veronesi B, Calderón-Garcidueñas L, Gehr P, Chen LC, Geiser $\mathrm{M}$, et al. Translocation and potential neurological effects of fine and ultrafine particles a critical update. Part Fibre Toxicol. (2006) 3:13. doi: 10.1186/1743-8977-3-13

83. Elder A, Gelein R, Silva V, Feikert T, Opanashuk L, Carter J, et al. Translocation of inhaled ultrafine manganese oxide particles to the central nervous system. Environ Health Perspect. (2006) 114:1172-8. doi: $10.1289 /$ ehp. 9030

84. Miller MR, Raftis JB, Langrish JP, McLean SG, Samutrtai P, Connell SP, et al. Inhaled nanoparticles accumulate at sites of vascular disease. ACS Nano (2017) 11:4542-52. doi: 10.1021/acsnano.6b08551

85. Lucarelli M, Gatti AM, Savarino G, Quattroni P, Martinelli L, Monari $\mathrm{E}$, et al. Innate defence functions of macrophages can be biased by nano-sized ceramic and metallic particles. Eur Cytokine Netw. (2004) 15:339-46. Available online at: http://www.jle.com/fr/revues/ecn/e-docs/ innate_defence_functions_of_macrophages_can_be_biased_by_nano_ sized_ceramic_and_metallic_particles_264246/

86. Bonner JC. Nanoparticles as a potential cause of pleural and interstitial lung disease. Proc Am Thor Soc. (2010) 7:138-41. doi: 10.1513/pats.200907-061RM

87. Byrne JD, Baugh JA. The significance of nanoparticles in particle-induced pulmonary fibrosis. McGill J Med. (2008) 11:43-50.

88. Lkhasuren O, Takahashi K, Dash-Onolt L. Occupational lung diseases and the mining industry in Mongolia. Int J Occup Env Health (2007) 13:195-201. doi: 10.1179/oeh.2007.13.2.195

89. Chen HW, Su SF, Chien CT, Lin WH, Yu SL, Chou CC, et al. Titanium dioxide nanoparticles induce emphysema-like lung injury in mice. FASEB J. (2006) 20:2393-5. doi: 10.1096/fj.06-6485fje

90. You R, Lu W, Shan M, Berlin JM, Samuel ELG, Marcano DC, et al. Nanoparticulate carbon black in cigarette smoke induces DNA cleavage and Th17-mediated emphysema. eLife (2015) 4:e09623. doi: 10.7554/eLife. 09623

91. Pankhurst Q, Hautot D, Khan N, Dobson J. Increased levels of magnetic iron compounds in Alzheimer's disease. J Alzheimers Dis. (2008) 13:49-52. doi: 10.3233/JAD-2008-13105

92. Hawkins SJ, Crompton LA, Sood A, Saunders M, Boyle NT, Buckley A, et al. Nanoparticle-induced neuronal toxicity across placental barriers is mediated by autophagy and dependent on astrocytes. Nat Nanotechnol. (2018) 13:427-33. doi: 10.1038/s41565-018-0085-3

93. Li X, Liu B, Li XL, Li YX, Sun MZ, Chen DY, et al. SiO(2) nanoparticles change colour preference and cause Parkinson's-like behaviour in zebrafish. Sci Rep. (2014) 4:3810. doi: 10.1038/srep03810

94. Itoh Y, Shimazu A, Sadzuka Y, Sonobe T, Itai S. Novel method for stratum corneum pore size determination using positron annihilation lifetime spectroscopy. Int J Pharm. (2008) 358:91-5. doi: 10.1016/j.ijpharm.2008.02.016

95. Borm PJ, Robbins D, Haubold S, Kuhlbusch T, Fissan H, Donaldson K, et al. The potential risks of nanomaterials: a review carried out for ECETOC. Toxicology (2006) 3:11. doi: 10.1186/1743-8977-3-11

96. Toll R, Jacobi U, Richter H, Lademann J, Schaefer H, BlumePeytavi U. Penetration profile of microspheres in follicular targeting of terminal hair follicles. J Investig Dermatol. (2004) 123:168-76. doi: 10.1111/j.0022-202X.2004.22717.x

97. Tinkle SS, Antonini JM, Rich BA, Roberts JR, Salmen R, DePree $\mathrm{K}$, et al. Skin as a route of exposure and sensitization in chronic beryllium disease. Environ Health Perspect. (2003) 111:1202-8. doi: 10.1289/ ehp.5999

98. Mocan T, Matea CT, Iancu C, Agoston-Coldea L, Mocan L, Orasan R. Hypersensitivity and nanoparticles: update and research trends. Clujul Med. (2016) 89:216-9. doi: 10.15386/cjmed-574

99. Hirai T, Yoshikawa T, Nabeshi H, Yoshida T, Tochigi S, Ichihashi KI, et al. Amorphous silica nanoparticles size-dependently aggravate atopic dermatitis-like skin lesions following an intradermal injection. Part Fibre Toxicol. (2012) 9:3-3. doi: 10.1186/1743-8977-9-3 
100. Yanagisawa R, Takano H, Inoue KI, Koike E, Kamachi T, Sadakane $\mathrm{K}$, et al. Titanium dioxide nanoparticles aggravate atopic dermatitislike skin lesions in NC/Nga mice. Exp Biol Med. (2009) 234:314-22. doi: 10.3181/0810-RM-304

101. Martirosyan A, Schneider YJ. Engineered nanomaterials in food: implications for food safety and consumer health. Int J Environ Res Public Health (2014) 11:5720-50. doi: 10.3390/ijerph110605720

102. Priyadarsini S, Mukherjee S, Mishra M. Nanoparticles used in dentistry: a review. J Oral Biol Craniof Res. (2018) 8:58-67. doi: 10.1016/j.jobcr.2017.12.004

103. Raj S, Jose S, Sumod US, Sabitha M. Nanotechnology in cosmetics: Opportunities and challenges. J Pharm Bioall Sci. (2012) 4:186-93. doi: 10.4103/0975-7406.99016

104. Bettini S, Houdeau E. [Oral exposure to titanium dioxide $(\mathrm{TiO}(2))$ nanoparticles: from translocation through oral and intestinal epithelia to fate and effects in the organism]. Biol Aujourd'hui (2014) 208:167-75. doi: $10.1051 /$ jbio/20140022

105. Lafuente D, Garcia T, Blanco J, Sánchez DJ, Sirvent JJ, Domingo JL, et al. Effects of oral exposure to silver nanoparticles on the sperm of rats. Reprod Toxicol. (2016) 60:133-9. doi: 10.1016/j.reprotox.2016.02.007

106. Balasubramanyam A, Sailaja N, Mahboob M, Rahman MF, Misra S, Hussain $\mathrm{SM}$, et al. Evaluation of genotoxic effects of oral exposure to Aluminum oxide nanomaterials in rat bone marrow. Mutat Res Gen Toxicol Environ Mutag. (2009) 676:41-7. doi: 10.1016/j.mrgentox.2009.03.004

107. Susana C, Lucía G, María Pilar V, Dolores V, Gorka S, Yurena L, et al. Safety assessment of chronic oral exposure to iron oxide nanoparticles. Nanotechnology (2015) 26:205101. doi: 10.1088/0957-4484/26/20/205101

108. Jia J, Li F, Zhou H, Bai Y, Liu S, Jiang Y, et al. Oral exposure to silver nanoparticles or silver ions may aggravate fatty liver disease in overweight mice. Environ Sci Technol. (2017) 51:9334-43. doi: 10.1021/acs.est.7b02752

109. Rabia Riasat NGZR, Imran A. Effects of nanoparticles on gastrointestinal disorders and therapy. J Clin Toxicol. (2016) 6:313. doi: 10.4172/2161-0495.1000313

110. Philbert MA. The new toxicology of sophisticated material: Nanotoxicology and beyond. Toxicol Lett. (2012) 211:S3. doi: 10.1016/j.toxlet.2012.03.019

111. Sharifi S, Behzadi S, Laurent S, Forrest ML, Stroeve P, Mahmoudi M. Toxicity of nanomaterials. Chem Soc Rev. (2012) 41:2323-43. doi: $10.1039 / \mathrm{C} 1 \mathrm{CS} 15188 \mathrm{~F}$

112. Stebounova LV, Morgan H, Grassian VH, Brenner S. Health and safety implications of occupational exposure to engineered nanomaterials. Wiley Interdiscip Rev Nanomed Nanobiotechnol. (2012) 4:310-21. doi: 10.1002/wnan.174

113. Campagnolo L, Massimiani M, Magrini A, Camaioni A, Pietroiusti A. Physico-chemical properties mediating reproductive and developmental toxicity of engineered nanomaterials. Curr Med Chem. (2012) 19:4488-94. doi: 10.2174/092986712803251566

114. Yu P, Sabine N, Annika L, Monika F, Fei W, Ulrich S, et al. Sizedependent cytotoxicity of gold nanoparticles. Small (2007) 3:1941-9. doi: 10.1002/smll.200700378

115. Malvindi MA, Brunetti V, Vecchio G, Galeone A, Cingolani R, Pompa PP. $\mathrm{SiO} 2$ nanoparticles biocompatibility and their potential for gene delivery and silencing. Nanoscale (2012) 4:486-95. doi: 10.1039/C1NR11269D

116. Armstrong N, Ramamoorthy M, Lyon D, Jones K, Duttaroy A. Mechanism of silver nanoparticles action on insect pigmentation reveals intervention of copper homeostasis. PLoS ONE (2013) 8 e53186. doi: 10.1371/journal.pone.0053186

117. Endocrine Disruptors. U.S. Department of Health and Human Services, National Institutes of Health (2010).

118. Zha L, Zeng J, Sun S, Deng H, Luo H, Li W. Chromium(III) nanoparticles affect hormone and immune responses in heat-stressed rats. Biol Trace Elem Res. (2009) 129:157-69. doi: 10.1007/s12011-008-8282-9

119. Wang $\mathrm{M}, \mathrm{Xu} \mathrm{Z}$, Li W, Jiang Z. Effect of chromium nanocomposite supplementation on growth hormone pulsatile secretion and mRNA expression in finishing pigs. J Anim Physiol Anim Nutr. (2009) 93:520-5. doi: 10.1111/j.1439-0396.2008.00836.x

120. Chen Z, Wang Y, Wang X, Zhuo L, Chen S, Tang S, et al. Effect of titanium dioxide nanoparticles on glucose homeostasis after oral administration. $J$ Appl Toxicol. (2018) 38:810-23. doi: 10.1002/jat.3589
121. Wang MQ, Xu ZR, Zha LY, Lindemann MD. Effects of chromium nanocomposite supplementation on blood metabolites, endocrine parameters and immune traits in finishing pigs. Anim Feed Sci Technol. (2007) 139:69-80. doi: 10.1016/j.anifeedsci.2006.12.004

122. Darbre PD. Endocrine disruption and disorders of energy metabolism. In: Darbre PD. editor. Endocrine Disruption and Human Health. Cambridge, MA: Academic Press (2015) p. 273-85.

123. Iavicoli I, Fontana L, Leso V, Bergamaschi A. The effects of nanomaterials as endocrine disruptors. Int J Mol Sci. (2013) 14:16732-801. doi: 10.3390/ijms 1408 16732

124. Birnbaum LS, Jung P. From endocrine disruptors to nanomaterials: advancing our understanding of environmental health to protect public health. Health Aff. (2011) 30:814-22. doi: 10.1377/hlthaff.2010.1225

125. Abdelhalim MAK, Jarrar BM. Gold nanoparticles administration induced prominent inflammatory, central vein intima disruption, fatty change and Kupffer cells hyperplasia. Lipids Health Dis. (2011) 10:133. doi: 10.1186/1476-511X-10-133

126. Sumbayev VV, Yasinska IM, Garcia CP, Gilliland D, Lall GS, Gibbs BF, et al. Gold nanoparticles downregulate interleukin-1 $\beta$-induced pro-inflammatory responses. Small (2013) 9:472-77. doi: 10.1002/smll.201201528

127. Stelzer R, Hutz RJ. Gold nanoparticles enter rat ovarian granulosa cells and subcellular organelles, and alter in-vitro estrogen accumulation. J Reprod Dev. (2009) 55:685-90. doi: 10.1262/jrd.20241

128. Sharma M, Salisbury RL, Maurer EI, Hussain SM, Sulentic EWC. Gold nanoparticles induce transcriptional activity of NF-[small kappa]B in a Blymphocyte cell line. Nanoscale (2013) 5:3747-56. doi: 10.1039/c3nr30071d

129. Tinkov AA, Gritsenko VA, Skalnaya MG, Cherkasov SV, Aaseth J, Skalny AV. Gut as a target for cadmium toxicity. Environ Pollut. (2018) 235:429-34. doi: 10.1016/j.envpol.2017.12.114

130. Shafrir E, Ziv E, Mosthaf L. Nutritionally induced insulin resistance and receptor defect leading to $\beta$-cell failure in animal models. Ann N Y Acad Sci. (1999) 892:223-46. doi: 10.1111/j.1749-6632.1999.tb07798.x

131. Hasnain SZ, Prins JB, McGuckin MA. Oxidative and endoplasmic reticulum stress in beta-cell dysfunction in diabetes. J Mol Endocrinol. (2016) 56:R3354. doi: 10.1530/JME-15-0232

132. Pilkington EH, Gurzov EN, Kakinen A, Litwak SA, Stanley WJ, Davis TP, et al. Pancreatic beta-cell membrane fluidity and toxicity induced by human islet amyloid polypeptide species. Sci Rep. (2016) 6:21274. doi: $10.1038 /$ srep 21274

133. Fu Z, Gilbert ER, Liu D. Regulation of insulin synthesis and secretion and pancreatic beta-cell dysfunction in diabetes. Curr Diabetes Rev. (2013) 9:25-53. doi: $10.2174 / 157339913804143225$

134. Yun C, Katchko KM, Schallmo MS, Jeong S, Yun J, Chen CH, et al. Aryl hydrocarbon receptor antagonists mitigate the effects of dioxin on critical cellular functions in differentiating human osteoblast-like cells. Int J Mol Sci. (2018) 19:E225. doi: 10.3390/ijms19010225

135. Le Marchand-Brustel Y, Jeanrenaud B, Freychet P. Insulin binding and effects in isolated soleus muscle of lean and obese mice. Am J Physiol Endocrinol Metab. (1978) 234:E348. doi: 10.1152/ajpendo.1978.234.4.E348

136. Saltiel AR, Kahn CR. Insulin signalling and the regulation of glucose and lipid metabolism. Nature (2001) 414799-806. doi: 10.1038/ $414799 \mathrm{a}$

137. Nadal A, Jm R, Laribi O, Leon-quinto T, Andreu E, Ripoll C, Soria B. Rapid insulinotropic effect of 17 beta-estradiol via a plasma membrane receptor. FASEB J. (2012) 12:1341-8. doi: 10.1096/fasebj.12. 13.1341

138. Gurevitch D, Shuster-Meiseles T, Nov O, Zick Y, Rudich A, Rudich Y. $\mathrm{TiO} 2$ nanoparticles induce insulin resistance in liver-derived cells both directly and via macrophage activation. Nanotoxicology (2012) 6:804-12. doi: $10.3109 / 17435390.2011 .625128$

139. Zha LY, Xu ZR, Wang MQ, Gu LY. Effects of chromium nanoparticle dosage on growth, body composition, serum hormones and tissue chromium in Sprague-Dawley rats. J Zhejiang Univ Sci B (2007) 8:323-30. doi: 10.1631/jzus.2007.B0323

140. Evans GW, Bowman TD. Chromium picolinate increases membrane fluidity and rate of insulin internalization. J Inorg Biochem. (1992) 46:243-50. doi: 10.1016/0162-0134(92)80034-S 
141. Ropero AB, Alonso-Magdalena P, Quesada I, Nadal A. The role of estrogen receptors in the control of energy and glucose homeostasis. Steroids (2008) 73:874-79. doi: 10.1016/j.steroids.2007.12.018

142. Alonso-Magdalena P, Ropero AB, Carrera MP, Cederroth CR, Baquié M, Gauthier BR, et al. Pancreatic insulin content regulation by the estrogen receptor ER $\alpha$. PLoS ONE (2008) 3:e2069. doi: 10.1371/journal.pone.0002069

143. Jain MP, Vaisheva F, Maysinger D. Metalloestrogenic effects of quantum dots. Nanomedicine (2012) 7:23-37. doi: 10.2217/nnm.11.102

144. Larson JK, Carvan MJ III, Hutz RJ. Engineered nanomaterials: an emerging class of novel endocrine disruptors. Biol Reprod (2014) 91:20. doi: 10.1095/biolreprod.113.116244

145. Schanen BC, Karakoti AS, Seal S, Drake Iii DR, Warren WL, Self WT. Exposure to titanium dioxide nanomaterials provokes inflammation of an in vitro human immune construct. ACS Nano (2009) 3:2523-32. doi: 10.1021/nn900403h

146. Khan H, Abdelhalim M, Alhomida A, Al Ayed M. Transient increase in IL-1 $\beta$, IL- 6 and TNF- $\alpha$ gene expression in rat liver exposed to gold nanoparticles. Genet Mol Res. (2013) 12:5851-7. doi: 10.4238/2013.November.22.12

147. Piret JP, Jacques D, Audinot JN, Mejia J, Boilan E, Noel F, et al. Copper(II) oxide nanoparticles penetrate into HepG2 cells, exert cytotoxicity via oxidative stress and induce pro-inflammatory response. Nanoscale (2012) 4:7168-84. doi: 10.1039/c2nr31785k

148. Bruun JM, Lihn AS, Verdich C, Pedersen SB, Toubro S, Astrup A, et al. Regulation of adiponectin by adipose tissue-derived cytokines: in vivo and in vitro investigations in humans. Am J Physiol Endocrinol Metab. (2003) 285:E527-33. doi: 10.1152/ajpendo.00110.2003

149. Han SG, Newsome B, Hennig B. Titanium dioxide nanoparticles increase inflammatory responses in vascular endothelial cells. Toxicology (2013) 306:1-8. doi: 10.1016/j.tox.2013.01.014

150. Tsai CY, Lu SL, Hu CW, Yeh CS, Lee GB, Lei HY. Size-dependent attenuation of TLR9 signaling by gold nanoparticles in macrophages. J Immunol. (2012) 188:68-76. doi: 10.4049/jimmunol.1100344

151. Turabekova M, Rasulev B, Theodore M, Jackman J, Leszczynska D, Leszczynski J. Immunotoxicity of nanoparticles: a computational study suggests that CNTs and C60 fullerenes might be recognized as pathogens by Toll-like receptors. Nanoscale (2014) 6:3488-95. doi: 10.1039/C3NR05772K

152. Ghoneum M, Ghoneum A, Gimzewski J. Nanodiamond and nanoplatinum liquid, DPV576, activates human monocyte-derived dendritic cells in vitro. Anticancer Res. (2010) 30:4075-9. Available online at: http://ar.iiarjournals. org/content/30/10/4075.short

153. Lasagna-Reeves C, Gonzalez-Romero D, Barria M, Olmedo I, Clos A, Ramanujam VS, et al. Bioaccumulation and toxicity of gold nanoparticles after repeated administration in mice. Biochem Biophys Res Commun. (2010) 393:649-55. doi: 10.1016/j.bbrc.2010.02.046

154. Hanley C, Thurber A, Hanna C, Punnoose A, Zhang J, Wingett DG. The influences of cell type and zno nanoparticle size on immune cell cytotoxicity and cytokine induction. Nanosc Res Lett. (2009) 4:1409-20. doi: 10.1007/s11671-009-9413-8

155. Freeman DJ, Norrie J, Caslake MJ, Gaw A, Ford I, Lowe GD, et al. West of scotland coronary prevention, C-reactive protein is an independent predictor of risk for the development of diabetes in the West of Scotland Coronary Prevention Study. Diabetes (2002) 51:1596-600. doi: 10.2337/diabetes.51.5.1596

156. Liu ZH, Ding Yl, Xiu LC, Pan HY, Liang Y, Zhong SQ, et al. A meta-analysis of the association between TNF- $\alpha-308 \mathrm{G}>\mathrm{A}$ polymorphism and type 2 diabetes mellitus in han chinese population. PLOS ONE (2013) 8:e59421. doi: 10.1371/journal.pone.0059421

157. Petersen AM, Pedersen BK. The anti-inflammatory effect of exercise. J Appl Physiol. (1985) 98:1154-62. doi: 10.1152/japplphysiol.00164.2004

158. Bastard JP, Jardel C, Bruckert E, Vidal H, Hainque B. Variations in plasma soluble tumour necrosis factor receptors after dietinduced weight loss in obesity. Diabetes Obes Metab. (2000) 2:323-5. doi: 10.1046/j.1463-1326.2000.00090.x

159. Fasshauer M, Paschke R. Regulation of adipocytokines and insulin resistance. Diabetologia (2003) 46:1594-603. doi: 10.1007/s00125-003-1228-Z

160. Mirza S, Hossain M, Mathews C, Martinez P, Pino P, Gay JL, et al. Type (2012) 2-diabetes is associated with elevated levels of TNF-alpha,
IL-6 and adiponectin and low levels of leptin in a population of Mexican Americans: a cross-sectional study. Cytokine (2012) 57:136-42. doi: 10.1016/j.cyto.2011.09.029

161. Prasad P, Tiwari A, Kumar P, Ammini A, Gupta A, Gupta R, et al. Association of TGFbeta1, TNFalpha, CCR2 and CCR5 gene polymorphisms in type2 diabetes and renal insufficiency among Asian Indians. BMC Med Genet. (2007) 8:20. doi: 10.1186/1471-2350-8-20

162. Prasad P, Kumar P, Ammini A, Gupta A, Gupta R, Thelma KB. Association of dopaminergic pathway gene polymorphisms with chronic renal insufficiency among Asian Indians with type-2 diabetes. BMC Genet. (2008) 9:26. doi: 10.1186/1471-2156-9-26

163. Prasad P, Tiwari A, Kumar P, Ammini A, Gupta A, Gupta R, et al. Chronic renal insufficiency among Asian Indians with type 2 diabetes: I. Role of RAAS gene polymorphisms. BMC Med Genet. (2006) 7:42. doi: 10.1186/1471-2350-7-42

164. Cantley LC. The phosphoinositide 3-kinase pathway. Science (2002) 296:1655-7. doi: 10.1126/science.296.5573.1655

165. Brown EJ, Albers MW, Bum Shin T, Ichikawa K, Keith CT, Lane WS, et al. A mammalian protein targeted by G1-arresting rapamycin-receptor complex. Nature (1994) 369:756-8. doi: 10.1038/369756a0

166. Gandhi S, Srinivasan BP, Akarte AS. An experimental assessment of toxic potential of nanoparticle preparation of heavy metals in streptozotocin induced diabetes. Exp Toxicol Pathol. (2013) 65:1127-35. doi: 10.1016/j.etp.2013.05.004

167. Sarkar A, Sil PC. Iron oxide nanoparticles mediated cytotoxicity via PI3K/AKT pathway: role of quercetin. Food Chem Toxicol. (2014) 71:106115. doi: 10.1016/j.fct.2014.06.003

168. Jomova K, Valko M. Advances in metal-induced oxidative stress and human disease. Toxicology (2011) 283:65-87. doi: 10.1016/j.tox.2011.03.001

169. Loh K, Deng H, Fukushima A, Cai X, Boivin B, Galic S, et al. Reactive oxygen species enhance insulin sensitivity. Cell Metab. (2009) 10:260-72. doi: 10.1016/j.cmet.2009.08.009

170. Houstis N, Rosen ED, Lander ES. Reactive oxygen species have a causal role in multiple forms of insulin resistance. Nature (2006) 440:944-8. doi: 10.1038/nature04634

171. Hailong H, Qian G, Changlin W, Xiao M, Hongjuan H, Yuri O, et al. Titanium dioxide nanoparticles increase plasma glucose via reactive oxygen species-induced insulin resistance in mice. J Appl Toxicol. (2015) 35:1122-32. doi: $10.1002 /$ jat. 3150

172. Maiese K. New insights for oxidative stress and diabetes mellitus. Oxid Med Cell Longev. (2015) 2015:875961. doi: 10.1155/2015/875961

173. Ashcroft FM, Rorsman P. Diabetes mellitus and the beta cell: the last ten years. Cell (2012) 148:1160-71. doi: 10.1016/j.cell.2012.02.010

174. Fonseca SG, Burcin M, Gromada J, Urano F. Endoplasmic reticulum stress in beta-cells and development of diabetes. Curr Opin Pharmacol. (2009) 9:763-70. doi: 10.1016/j.coph.2009.07.003

175. Könczöl M, Ebeling S, Goldenberg E, Treude F, Gminski R, Gieré R, et al. Cytotoxicity and genotoxicity of size-fractionated iron oxide (Magnetite) in A549 human lung epithelial cells: role of ROS, JNK, and NF-кB. Chem Res Toxicol. (2011) 24:1460-75. doi: 10.1021/tx200051s

176. Nan C, Hui W, Qing H, Jiang L, Juan Y, Dannong H, et al. Long-term effects of nanoparticles on nutrition and metabolism. Small (2014) 10:3603-11. doi: 10.1002/smll.201303635

177. Bai L, Chen H, Hatzopoulou M, Jerrett M, Kwong JC, Burnett RT, et al. Exposure to ambient ultrafine particles and nitrogen dioxide and incident hypertension and diabetes. Epidemiology (2018) 29:323-32. doi: 10.1097/EDE.0000000000000798

178. Singh P, Kim YJ, Zhang D, Yang DC. Biological synthesis of nanoparticles from plants and microorganisms. Trends Biotechnol. (2016) 34:588-99. doi: $10.1016 /$ j.tibtech.2016.02.006

179. Ingale AG, Chaudhari AN. Biogenic synthesis of nanoparticles and potential applications: an eco- friendly approach. J Nanomed Nanotechnol. (2013) 4:165. doi: 10.4172/2157-7439.1000165

180. Campoy AHG, Gutierrez RMP, Manriquez-Alvirde G, Ramirez AM. Protection of silver nanoparticles using Eysenhardtia polystachya in peroxide-induced pancreatic $\beta$-cell damage and their antidiabetic properties in zebrafish. Int J Nanomed. (2018) 13:2601. doi: 10.2147/IJN.S1 63714 
181. Venkatachalam M, Govindaraju K, Mohamed Sadiq A, Tamilselvan S, Ganesh Kumar V, Singaravelu G. Functionalization of gold nanoparticles as antidiabetic nanomaterial. Spectroch Acta Part A (2013) 116:331-8. doi: 10.1016/j.saa.2013.07.038

182. Karthick V, Kumar VG, Dhas TS, Singaravelu G, Sadiq AM, Govindaraju K. Effect of biologically synthesized gold nanoparticles on alloxan-induced diabetic rats-An in vivo approach. Coll Surf $B$ Biointerfaces (2014) 122:505-11. doi: 10.1016/j.colsurfb.2014. 07.022

183. Liu Y, Cao ZT, Xu CF, Lu ZD, Luo YL, Wang J. Optimization of lipidassisted nanoparticle for disturbing neutrophils-related inflammation. Biomaterials (2018) 172:92-104. doi: 10.1016/j.biomaterials.2018. 04.052

184. Jean M, Alameh M, De Jesus D, Thibault M, Lavertu M, Darras V, et al. Chitosan-based therapeutic nanoparticles for combination gene therapy and gene silencing of in vitro cell lines relevant to type 2 diabetes. Eur J Pharmac Sci. (2012) 45:138-49. doi: 10.1016/j.ejps.2011. 10.029

185. Rastogi R, Anand S, Koul V. Electroporation of polymeric nanoparticles: an alternative technique for transdermal delivery of insulin. Drug Dev Industrial Pharma. (2010) 36:1303-11. doi: 10.3109/03639041003786193

186. Patil NH, Devarajan PV. Insulin-loaded alginic acid nanoparticles for sublingual delivery. Drug Deliv. (2016) 23:429-36. doi: $10.3109 / 10717544.2014 .916769$

187. Salvioni L, Fiandra L, Del Curto MD, Mazzucchelli S, Allevi R, Truffi M, et al. Oral delivery of insulin via polyethylene imine-based nanoparticles for colonic release allows glycemic control in diabetic rats. Pharmacol Res. (2016) 110:122-30. doi: 10.1016/j.phrs.2016.05.016

188. Yuejie C, Demin Y, Penghua W, Jun X, Daiqing L, Min D. Nanotechnology promotes the full-thickness diabetic wound healing effect of recombinant human epidermal growth factor in diabetic rats. Wound Repair Regener. (2010) 18:499-505. doi: 10.1111/j.1524-475X.2010.00612.x

189. Damge C, Michel C, Aprahamian M, Couvreur P. New approach for oral administration of insulin with polyalkylcyanoacrylate nanocapsules as drug carrier. Diabetes (1988) 37:246-51. doi: 10.2337/diab.37.2.246

190. Zion TC, Tsang HH, Ying JY. Glucose-sensitive nanoparticles for controlled insulin delivery. Int J Nanomed. (2003) 12:4037-57. Available online at: http://hdl.handle.net/1721.1/3783

191. Gu Z, Aimetti AA, Wang Q, Dang TT, Zhang Y, Veiseh O, et al. Injectable nano-network for glucose-mediated insulin delivery. ACS Nano (2013) 7:4194-201. doi: 10.1021/nn400630x

192. Shilo M, Berenstein P, Dreifuss T, Nash Y, Goldsmith G, Kazimirsky $\mathrm{G}$, et al. Insulin-coated gold nanoparticles as a new concept for personalized and adjustable glucose regulation. Nanoscale (2015) 7:2048996. doi: 10.1039/C5NR04881H
193. Joshi HM, Bhumkar DR, Joshi K, Pokharkar V, Sastry M. Gold nanoparticles as carriers for efficient transmucosal insulin delivery. Langmuir (2006) 22:300-5. doi: 10.1021/la051982u

194. Lee KC, Chen WJ, Chen YC. Using dextran-encapsulated gold nanoparticles as insulin carriers to prolong insulin activity. Nanomedicine (2017) 12:182334. doi: 10.2217/nnm-2017-0019

195. Zhao Y, Trewyn BG, Slowing, II, Lin VS. Mesoporous silica nanoparticlebased double drug delivery system for glucose-responsive controlled release of insulin and cyclic AMP. J Am Chem Soc. (2009) 131:8398-400. doi: 10.1021/ja901831u

196. Deng W, Xie Q, Wang H, Ma Z, Wu B, Zhang X. Selenium nanoparticles as versatile carriers for oral delivery of insulin: insight into the synergic antidiabetic effect and mechanism. Nanomed Nanotechnol Biol Med. (2017) 13:1965-74. doi: 10.1016/j.nano.2017.05.002

197. Pourkhalili N, Hosseini A, Nili-Ahmadabadi A, Rahimifard M, NavaeiNigjeh M, Hassani S, et al. Improvement of isolated rat pancreatic islets function by combination of cerium oxide nanoparticles/sodium selenite through reduction of oxidative stress. Toxicol Mech Methods. (2012) 22:47682. doi: 10.3109/15376516.2012.673093

198. Asani SC, Umrani RD, Paknikar KM. Differential dose-dependent effects of zinc oxide nanoparticles on oxidative stress-mediated pancreatic $\beta$-cell death. Nanomedicine (2017) 12:745-59. doi: 10.2217/nnm-2016-0426

199. Septiadi D, Crippa F, Moore TL, Rothen-Rutishauser B, Petri-Fink A. Nanoparticle-cell interaction: a cell mechanics perspective. Adv Mater. (2018) 30:1704463. doi: 10.1002/adma.201704463

200. Wan HT, Leung PY, Zhao YG, Wei X, Wong MH, Wong CK. Blood plasma concentrations of endocrine disrupting chemicals in Hong Kong populations. J Hazard Mater (2013) 261:763-9. doi: 10.1016/j.jhazmat.2013.01.034

201. Lai RWS, Yeung KWY, Yung MMN, Djurisic AB, Giesy JP, Leung KMY. Regulation of engineered nanomaterials: current challenges, insights and future directions. Environ Sci Pollut Res Int. (2018) 25:3060-77. doi: 10.1007/s11356-017-9489-0

Conflict of Interest Statement: The authors declare that the research was conducted in the absence of any commercial or financial relationships that could be construed as a potential conflict of interest.

Copyright (c) 2018 Priyam, Singh and Gehlout. This is an open-access article distributed under the terms of the Creative Commons Attribution License (CC BY). The use, distribution or reproduction in other forums is permitted, provided the original author(s) and the copyright owner(s) are credited and that the original publication in this journal is cited, in accordance with accepted academic practice. No use, distribution or reproduction is permitted which does not comply with these terms. 